\title{
Framework for Evaluating Water Quality of the New England Crystalline Rock Aquifers
}

By Philip T. Harte, Gilpin R. Robinson, Jr., Joseph D. Ayotte, and

Sarah M. Flanagan

National Water-Quality Assessment Program

Open-File Report 2008-1282 


\title{
U.S. Department of the Interior DIRK KEMPTHORNE, Secretary
}

\author{
U.S. Geological Survey \\ Mark D. Myers, Director
}

U.S. Geological Survey, Reston, Virginia: 2008

For more information on the USGS — the Federal source for science about the Earth, its natural and living resources, natural hazards, and the environment:

World Wide Web: http://www.usgs.gov

Telephone: 1-888-ASK-USGS

Any use of trade, product, or firm names is for descriptive purposes only and does not imply endorsement by the U.S. Government.

Although this report is in the public domain, permission must be secured from the individual copyright owners to reproduce any copyrighted materials contained within this report.

Suggested citation:

Harte, P.T., Robinson, G.R., Jr., Ayotte, J.D., and Flanagan, S.F., 2008, Framework for evaluating water quality of the New England crystalline rock aquifers: U.S. Geological Survey Open-File Report 2008-1282, 47 p., available only online at http://pubs.usgs.gov/of/2008/1282. 


\section{Foreword}

\section{National Water-Quality Assessment (NAWOA) Program}

The U.S. Geological Survey (USGS) is committed to providing the Nation with credible scientific information that helps to enhance and protect the overall quality of life and that facilitates effective management of water, biological, energy, and mineral resources (http://www.usgs.gov/). Information on the Nation's water resources is critical to ensuring long-term availability of water that is safe for drinking and recreation and is suitable for industry, irrigation, and fish and wildlife. Population growth and increasing demands for water make the availability of that water, now measured in terms of quantity and quality, even more essential to the long-term sustainability of our communities and ecosystems.

The USGS implemented the National Water-Quality Assessment (NAWOA) Program in 1991 to support national, regional, State, and local information needs and decisions related to water-quality management and policy (http://water.usgs.gov/nawqa). The NAWQA Program is designed to answer: What is the condition of our Nation's streams and ground water? How are conditions changing over time? How do natural features and human activities affect the quality of streams and ground water, and where are those effects most pronounced? By combining information on water chemistry, physical characteristics, stream habitat, and aquatic life, the NAWQA Program aims to provide science-based insights for current and emerging water issues and priorities. From 1991-2001, the NAWQA Program completed interdisciplinary assessments and established a baseline understanding of water-quality conditions in 51 of the Nation's river basins and aquifers, referred to as Study Units (http://water.usgs.gov/nawqa/studyu.html).

In the second decade of the Program (2001-2012), a major focus is on regional assessments of water-quality conditions and trends. These regional assessments are based on major river basins and principal aquifers, which encompass larger regions of the country than the Study Units. Regional assessments extend the findings in the Study Units by filling critical gaps in characterizing the quality of surface water and ground water, and by determining status and trends at sites that have been consistently monitored for more than a decade. In addition, the regional assessments continue to build an understanding of how natural features and human activities affect water quality. Many of the regional assessments employ modeling and other scientific tools, developed on the basis of data collected at individual sites, to help extend knowledge of water quality to unmonitored, yet comparable areas within the regions. The models thereby enhance the value of our existing data and our understanding of the hydrologic system. In addition, the models are useful in evaluating various resource-management scenarios and in predicting how our actions, such as reducing or managing nonpoint and point sources of contamination, land conversion, and altering flow and (or) pumping regimes, are likely to affect water conditions within a region.

Other activities planned during the second decade include continuing national syntheses of information on pesticides, volatile organic compounds (VOCs), nutrients, selected trace elements, and aquatic ecology; and continuing national topical studies on the fate of agricultural chemicals, effects of urbanization on stream ecosystems, bioaccumulation of mercury in stream ecosystems, effects of nutrient enrichment on stream ecosystems, and transport of contaminants to public-supply wells. 
The USGS aims to disseminate credible, timely, and relevant science information to address practical and effective water-resource management and strategies that protect and restore water quality. We hope this NAWQA publication will provide you with insights and information to meet your needs, and will foster increased citizen awareness and involvement in the protection and restoration of our Nation's waters.

The USGS recognizes that a national assessment by a single program cannot address all waterresource issues of interest. External coordination at all levels is critical for cost-effective management, regulation, and conservation of our Nation's water resources. The NAWQA Program, therefore, depends on advice and information from other agencies-Federal, State, regional, interstate, Tribal, and local — as well as nongovernmental organizations, industry, academia, and other stakeholder groups. Your assistance and suggestions are greatly appreciated.

Matthew C. Larsen

Associate Director for Water 


\section{Acknowledgments}

The authors thank Kelly L. Warner, the NAWQA project leader of the Glacial, Cambrian-

Ordovician, and New England Crystalline Rock Aquifers studies, for her guidance and support of this report. Multiple reviewers provided important comments on parts of this report, including Dr. Stephen B. Mabee of the University of Massachusetts. 
THIS PAGE INTENTIONALLY LEFT BLANK 


\section{Contents}

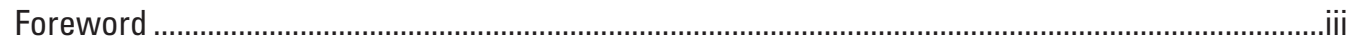

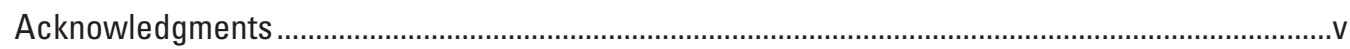

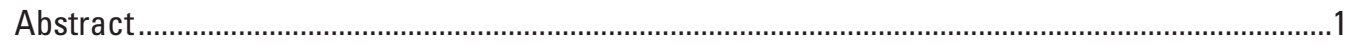

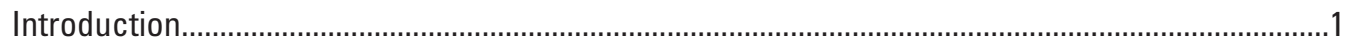

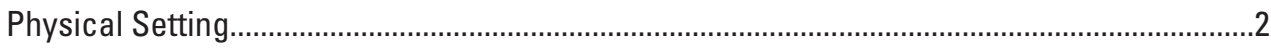

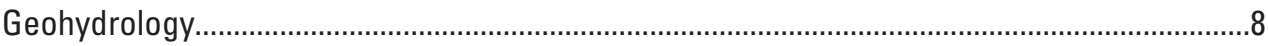

Identification of Regional Water-Quality Issues ....................................................................

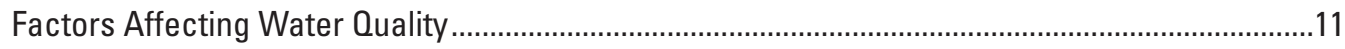

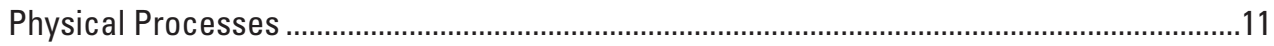

Chemical Processes......................................................................................................... 14

Considerations for Development of Regional Framework .................................................................15

Review of Other Framework Approaches ..........................................................................15

Discussion of Regional Framework Factors ............................................................................20

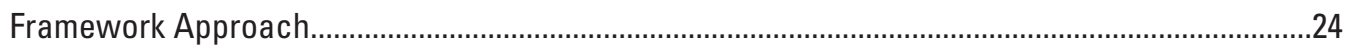

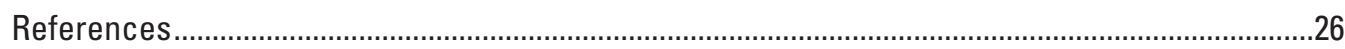

Appendix 1. Summary of Regional Ground-Water Quality Issues in Ground Water of the New England Area, by State, as Reported by State Environmental Agencies ....................36

\section{Figures}

1-4. Maps showing-

1. Location of the New England crystalline rock aquifers .............................................

2. Long-term mean annual precipitation (1960-1991) and physiography for the northeastern United States ...................................................................................... 4

3. Land use patterns in the New England area ...............................................................5

4. Geologic provinces in the New England crystalline rock aquifers ...........................7

5. Schematic diagrams showing hypothetical depth of well and fracture patterns in $(A)$ shallow wells and $(B)$ deep wells in the New England crystalline rock aquifers......13

6. Scatterplots showing relation between residence time and $(A) \mathrm{pH},(B)$ dissolved oxygen, and $(C)$ arsenic from crystalline rock ground water of the New England Coastal Basins

7. Flowchart showing objectives from a proposed 1990 study of the hydrogeology of bedrock of New England

8-9. Maps showing-

8. General lithology distribution of rock group A in the New England crystalline rock aquifers.

9. Lithology distribution of rock group B in the New England crystalline rock aquifers.

10. Flowchart showing preliminary framework approach for the evaluation of regional ground-water quality in the New England crystalline rock aquifers 


\section{Tables}

1. Approximate land use distribution, by percent, in the New England crystalline rock aquifers.

2. Summary of well characteristics in crystalline rock aquifers in New England, by State

3. Summary of regional ground-water quality issues in the New England crystalline rock aquifers as reported by previous NAWOA studies

4. Summary of factors affecting regional water quality in crystalline rocks of the New England area

5. Lithology groups and their respective area fractions for the New England crystalline rock aquifers.

6. Categories of spatial features, associated explanatory variables, sources of information, and ground-water contaminants to be evaluated for the regional study of the New England crystalline rock aquifers.

7. Ground-water contaminants in relation to explanatory variables in regional studies in the New England crystalline rock aquifers 


\section{Conversion Factors and Datum}

\begin{tabular}{|c|c|c|}
\hline Multiply & By & To obtain \\
\hline \multicolumn{3}{|c|}{ Length } \\
\hline foot $(\mathrm{ft})$ & 0.3048 & meter $(\mathrm{m})$ \\
\hline mile (mi) & 1.609 & kilometer $(\mathrm{km})$ \\
\hline \multicolumn{3}{|c|}{ Area } \\
\hline square mile $\left(\mathrm{mi}^{2}\right)$ & 2.590 & square kilometer $\left(\mathrm{km}^{2}\right)$ \\
\hline \multicolumn{3}{|c|}{ Volume } \\
\hline gallon (gal) & 3.785 & liter (L) \\
\hline million gallons (Mgal) & 3,785 & cubic meter $\left(\mathrm{m}^{3}\right)$ \\
\hline \multicolumn{3}{|c|}{ Flow rate } \\
\hline cubic foot per second $\left(\mathrm{ft}^{3} / \mathrm{s}\right)$ & 0.02832 & cubic meter per second $\left(\mathrm{m}^{3} / \mathrm{s}\right)$ \\
\hline gallon per minute (gal/min) & 0.06309 & liter per second (L/s) \\
\hline gallon per day (gal/d) & 0.003785 & cubic meter per day $\left(\mathrm{m}^{3} / \mathrm{d}\right)$ \\
\hline million gallons per day (Mgal/d) & 0.04381 & cubic meter per second $\left(\mathrm{m}^{3} / \mathrm{s}\right)$ \\
\hline inch per year (in/yr) & 25.4 & millimeter per year (mm/yr) \\
\hline \multicolumn{3}{|c|}{ Radioactivity } \\
\hline picocurie per liter (pCi/L) & 0.037 & becquerel per liter (Bq/L) \\
\hline \multicolumn{3}{|c|}{ Specific capacity } \\
\hline $\begin{array}{l}\text { gallon per minute per foot } \\
\qquad[(\mathrm{gal} / \mathrm{min}) / \mathrm{ft})]\end{array}$ & 0.2070 & $\begin{array}{l}\text { liter per second per meter } \\
\qquad[(\mathrm{L} / \mathrm{s}) / \mathrm{m}]\end{array}$ \\
\hline \multicolumn{3}{|c|}{ Hydraulic conductivity } \\
\hline foot per day (ft/d) & 0.3048 & meter per day $(\mathrm{m} / \mathrm{d})$ \\
\hline \multicolumn{3}{|c|}{ Hydraulic gradient } \\
\hline foot per mile (ft/mi) & 0.1894 & meter per kilometer $(\mathrm{m} / \mathrm{km})$ \\
\hline \multicolumn{3}{|c|}{ Transmissivity* } \\
\hline foot squared per day $\left(\mathrm{ft}^{2} / \mathrm{d}\right)$ & 0.09290 & meter squared per day $\left(\mathrm{m}^{2} / \mathrm{d}\right)$ \\
\hline \multicolumn{3}{|c|}{ Application rate } \\
\hline $\begin{array}{l}\text { pounds per acre per year } \\
\text { [(lb/acre }) / \mathrm{yr}]\end{array}$ & 1.121 & $\begin{array}{l}\text { kilograms per hectare per year } \\
{[(\mathrm{kg} / \mathrm{ha}) / \mathrm{yr}]}\end{array}$ \\
\hline \multicolumn{3}{|c|}{ Mass } \\
\hline $\operatorname{gram}(\mathrm{g})$ & 0.03527 & ounce, avoirdupois (oz) \\
\hline
\end{tabular}


Temperature in degrees Fahrenheit $\left({ }^{\circ} \mathrm{F}\right)$ may be converted to degrees Celsius $\left({ }^{\circ} \mathrm{C}\right)$ as follows: ${ }^{\circ} \mathrm{C}=\left({ }^{\circ} \mathrm{F}-32\right) / 1.8$

Vertical coordinate information is referenced to the North American Vertical Datum of 1988 (NAVD 88). Altitude, as used in this report, refers to distance above the vertical datum.

Horizontal coordinate information is referenced to the North American Datum of 1983 (NAD 83).

*Transmissivity: The standard unit for transmissivity is cubic foot per day per square foot times foot of aquifer thickness $\left[\left(\mathrm{ft}^{3} / \mathrm{d}\right) / \mathrm{ft}^{2}\right] \mathrm{ft}$. In this report, the mathematically reduced form, foot squared per day $\left(\mathrm{ft}^{2} / \mathrm{d}\right)$, is used for convenience.

Specific conductance is given in microsiemens per centimeter at 25 degrees Celsius $\left(\mu \mathrm{S} / \mathrm{cm}\right.$ at $\left.25^{\circ} \mathrm{C}\right)$.

Concentrations of chemical constituents in water are given either in milligrams per liter (mg/L) or micrograms per liter $(\mu \mathrm{g} / \mathrm{L})$. 


\title{
Framework for Evaluating Water Quality of the New England Crystalline Rock Aquifers
}

\author{
By Philip T. Harte, Gilpin R. Robinson, Jr., Joseph D. Ayotte, and Sarah M. Flanagan
}

\section{Abstract}

Little information exists on regional ground-waterquality patterns for the New England crystalline rock aquifers (NECRA). A systematic approach to facilitate regional evaluation is needed for several reasons. First, the NECRA are vulnerable to anthropogenic and natural contaminants such as methyl tert-butyl ether (MTBE), arsenic, and radon gas. Second, the physical characteristics of the aquifers, termed "intrinsic susceptibility," can lead to variable and degraded water quality. A framework approach for characterizing the aquifer region into areas of similar hydrogeology is described in this report and is based on hypothesized relevant physical features and chemical conditions (collectively termed "variables") that affect regional patterns of ground-water quality.

A framework for comparison of water quality across the NECRA consists of a group of spatial variables related to aquifer properties, hydrologic conditions, and contaminant sources. These spatial variables are grouped under four general categories (features) that can be mapped across the aquifers: (1) geologic, (2) hydrophysiographic, (3) land-use land-cover, and (4) geochemical. On a regional scale, these variables represent indicators of natural and anthropogenic sources of contaminants, as well as generalized physical and chemical characteristics of the aquifer system that influence ground-water chemistry and flow. These variables can be used in varying combinations (depending on the contaminant) to categorize the aquifer into areas of similar hydrogeologic characteristics to evaluate variation in regional water quality through statistical testing.

\section{Introduction}

The New England crystalline rock aquifers (NECRA) are one of 19 principal aquifers selected by the U.S. Geological Survey (USGS) National Water-Quality Assessment (NAWQA) Program for regional assessment of ground-water quality (Lapham and others, 2005). A principal aquifer is defined as a regionally extensive group of aquifers or an aquifer system that has the potential to be used as a source of potable water (U.S. Geological Survey, 2003). The NECRA is an important regional source of ground water. Irrigation, public supply, and self-supplied industrial water use from the NECRA total more than $96.3 \mathrm{Mgal} / \mathrm{d}$ in 2000 (Maupin and Barber, 2005). Domestic water usage may exceed that total (Hutson and others, 2004).

The NECRA are composed primarily of igneous and metamorphic rocks with little primary porosity and permeability. Ground-water flow and transport occurs mainly through fractures, joints, and faults (U.S. Geological Survey, 2003) formed during or after rock formation. Where glacial deposits are thin or nonexistent in the northeastern United States, crystalline rock is the primary source of ground water. The geochemistry of the NECRA is different from that of other bedrock aquifers in the Northeastern United States in that dissolved solids are relatively low and geochemical reactions are dominated by dissolved carbon dioxide $\left(\mathrm{CO}_{2}\right)$ reacting with feldspathic minerals (Rogers, 1989).

The NECRA are vulnerable to natural and anthropogenic sources of contaminants. Vulnerability of an aquifer incorporates the intrinsic susceptibility of the aquifer, the physical features of the aquifer, and the proximity and characteristics of the contaminant sources (Focazio and others, 2002).

The following are quotations from Intrinsic Susceptibility and Vulnerability of Ground Water (from Focazio and others, 2002):

The intrinsic susceptibility of a ground-water system depends on the aquifer properties (hydraulic conductivity, porosity, hydraulic gradients) and the associated sources of water and stresses for the system (recharge, interactions with surface water, travel through the unsaturated zone, and well discharge). In this way, intrinsic susceptibility assessments do not target specific natural or anthropogenic sources of contamination but instead consider only the physical factors affecting the flow of water to, and through, the ground-water resource.

The vulnerability of a ground-water resource to contamination depends on intrinsic susceptibility as well as the locations and types of sources of naturally occurring and anthropogenic contamination, relative locations of wells, and the fate and transport of the contaminant(s). Water-resource decision makers are often faced with a choice of deciding whether to manage a resource based on knowledge of intrinsic susceptibility or to target more comprehensive and contaminant-specific assessments of vulnerability. 
Several carcinogenic contaminants have been measured at high (above U.S. Environmental Protection Agency Maximum Contaminant Level (MCL)) concentrations in ground water collected from the NECRA. For example, ground water collected from metasedimentary units and nearby granitic intrusions of the crystalline rock aquifers has been found to contain arsenic concentrations greater than $10 \mu \mathrm{g} / \mathrm{L}$, the U.S. Environmental Protection Agency MCL (Ayotte and others, 2003; Lipfert and others, 2006; U.S. Environmental Protection Agency, 2006). Concentrations of ${ }^{222}$ radon gas in excess of a U.S. Environmental Protection Agency proposed MCL of $300 \mathrm{pCi} / \mathrm{L}$ in water occurs in greater than 90 percent of domestic wells tapping crystalline rock aquifers of New Hampshire (Moore, 2004; Ayotte and others, 2007). Uranium concentrations in ground water from the NECRA also rank high compared to concentrations in other aquifers in northern parts of the United States (Ayotte and others, 2007). The relatively low permeability of bedrock in the NECRA has been hypothesized to make the aquifers susceptible to methyl tert-butyl ether (MTBE), a gasoline oxygenate because of relatively low amounts of dilution to source inputs (Ayotte and others, 2005, 2008).

This report summarizes regional ground-water-quality issues in the NECRA, categorizes some spatial patterns in regional ground-water quality that have been reported from regional and local studies, and proposes a methodology or "framework" on how a multicontaminant assessment of aquifer vulnerability to contamination can be evaluated on a regional scale. Regional ground-water quality is described in terms of natural and anthropogenic contaminants because of environmental concerns about their presence and variation in contaminant sources (termed "source input"). The framework for comparison of water quality across the NECRA consists of a group of spatial variables related to aquifer properties, hydrogeologic conditions, and contaminant sources. The framework is designed to characterize this large aquifer into areas of similar hydrogeologic characteristics and contaminant sources; the framework will be used in a planned study (2008-2011) of the regional ground-water quality of the NECRA (Kelly L. Warner, U.S. Geological Survey, written commun., 2007).

This study of the NECRA is part of the NAWQA Program's regional assessment of ground-water-quality conditions and trends (Lapham and others, 2005). These regional assessments are based on spatial analysis and temporal trends in principal aquifers, such as the NECRA, which encompass large regions of the country. Several NAWQA studies have been completed in the region, and those study units overlap all or parts of the NECRA. Previous NAWQA studies in order of decreasing land area within the NECRA include the New England Coastal Basin (NECB) study; Connecticut, Housatonic, and Thames River Basins (CONN) study; and Long Island-New Jersey Drainage Basins (LINJ) study. The NECB and CONN study units overlap almost entirely within the NECRA study area, whereas the LINJ study lies primarily outside. Sampled wells in the
NECRA from these previous NAWQA studies are shown in figure 1 . The sampled wells were domestic bedrock wells chosen randomly using a random spatial generator selection process (Scott, 1990) for the CONN and LINJ, and a filtered (based on bedrock type and lithochemistry) random selection process for the NECB.

The distribution of wells sampled in the LINJ (northern New Jersey) is clustered into a small area (fig. 1). For these reasons, the planned regional study of the NECRA (Kelly L. Warner, U.S. Geological Survey, written commun., 2007) will focus primarily on the New England part of the NECRA.

\section{Physical Setting}

The NECRA underlie an area of approximately $72,000 \mathrm{mi}^{2}$. It includes small parts of northern New Jersey, a narrow band across southern New York, and the New England states of Connecticut, Massachusetts, Vermont, Rhode Island, New Hampshire, and Maine. For the most part, the aquifer is covered by glacial drift, and younger unconsolidated deposits and bedrock exposures are few and small. Overburden thickness can range from zero to more than $100 \mathrm{ft}$ (Kontis and others, 2004). The entire aquifer is north of the Wisconsinan terminal moraine.

The terrain underlain by the NECRA has been divided by Fenneman (1938) from west to east into the Taconic Highlands, Green Mountains, New England Uplands, Seaboard Lowlands, and White Mountains (fig. 2). The largest peaks are in the White Mountains. Altitude of the terrain ranges from sea level to greater than $6,000 \mathrm{ft}$.

Land use ranges from urban to rural agricultural and forest, and it reflects population distribution and other cultural and physiographic features of the area (table 1). Population of the entire study area exceeds 15 million, and population density is greatest along the seacoast. Most urban centers are within the coastal high-population-density corridor (fig. 3). Agricultural areas make up 8.1 percent of the land area.

The study area can be divided into climatic regions based on proximity to the seacoast, orographic effects, and regional trends. Kontis and others (2004) show three climatic regions that trend northeast-southwest. Flanagan and others (1999) show a similar distribution of climatic regions that generally parallels the seacoast, based on data from the U.S. Department of Commerce (1977, 1982a, 1982b, 1982c) data. Mean annual air temperature ranges from 40 to $53^{\circ} \mathrm{F}$ (Kontis and others, 2004), with the coldest temperatures in the Adirondacks and northern Maine. Mean annual precipitation (1961-90) ranges from less than 34 to greater than $60 \mathrm{in} / \mathrm{yr}$ in high-relief areas of the Green Mountains, and White Mountains (fig. 2). Other high-precipitation areas include coastal areas of Connecticut and Maine.

Mean annual runoff incorporates the effects of climate, precipitation, evapotranspiration, topography, soils, and other watershed characteristics (Kontis and others, 2004). A map of long-term mean annual runoff for the northeastern United 


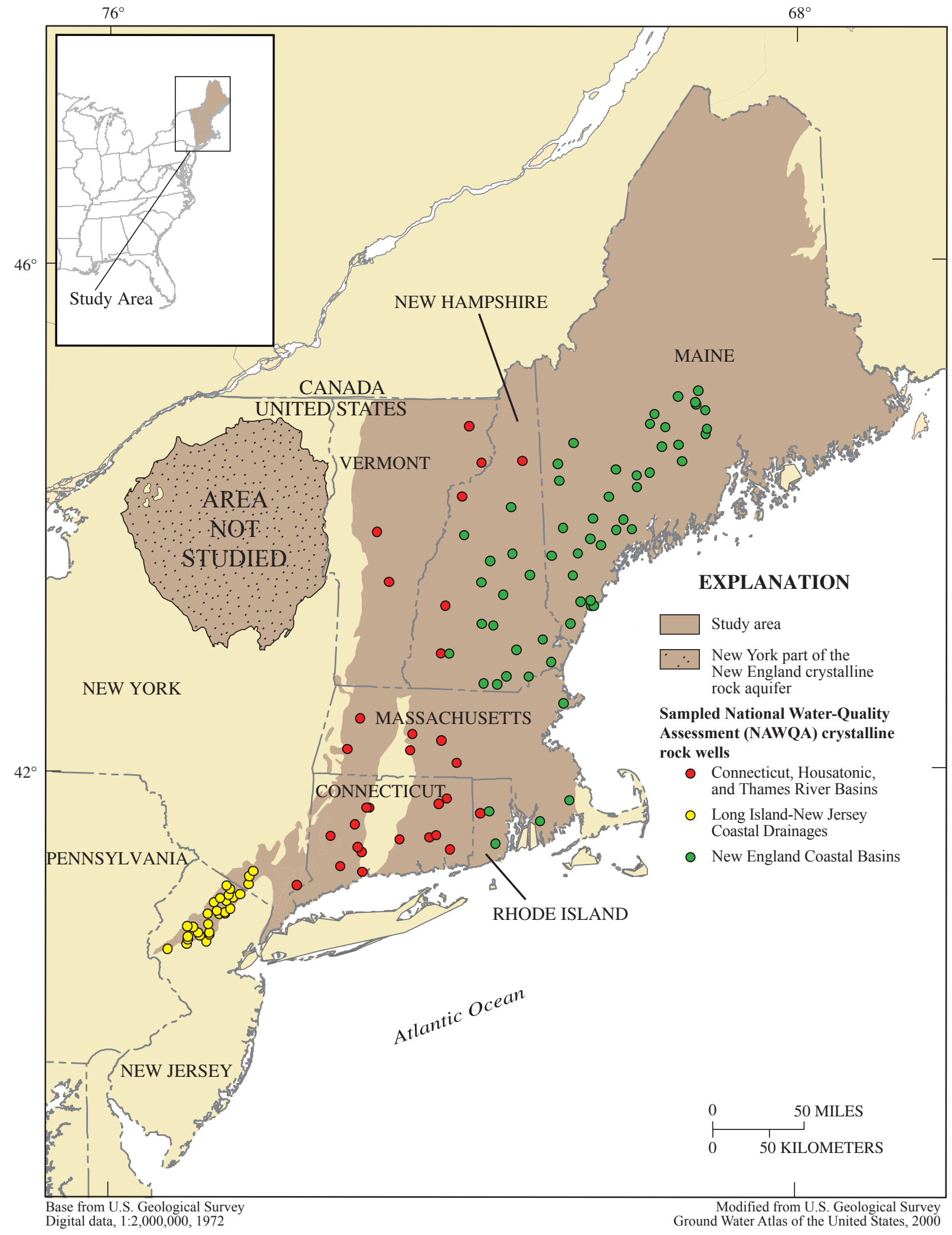

Figure 1. Location of the New England crystalline rock aquifers. 


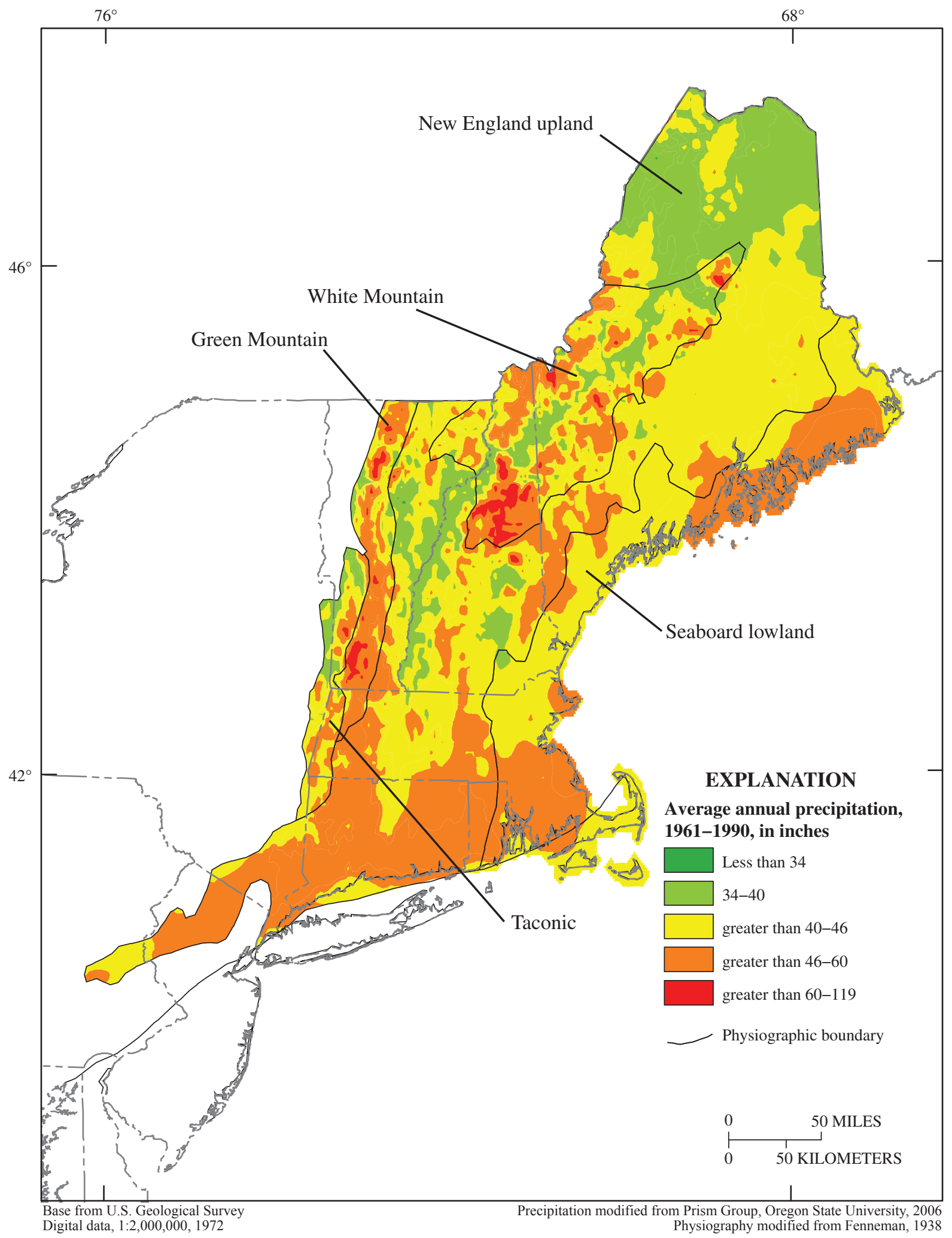

Figure 2. Long-term mean annual precipitation (1960-1991) and physiography for the northeastern United States. 


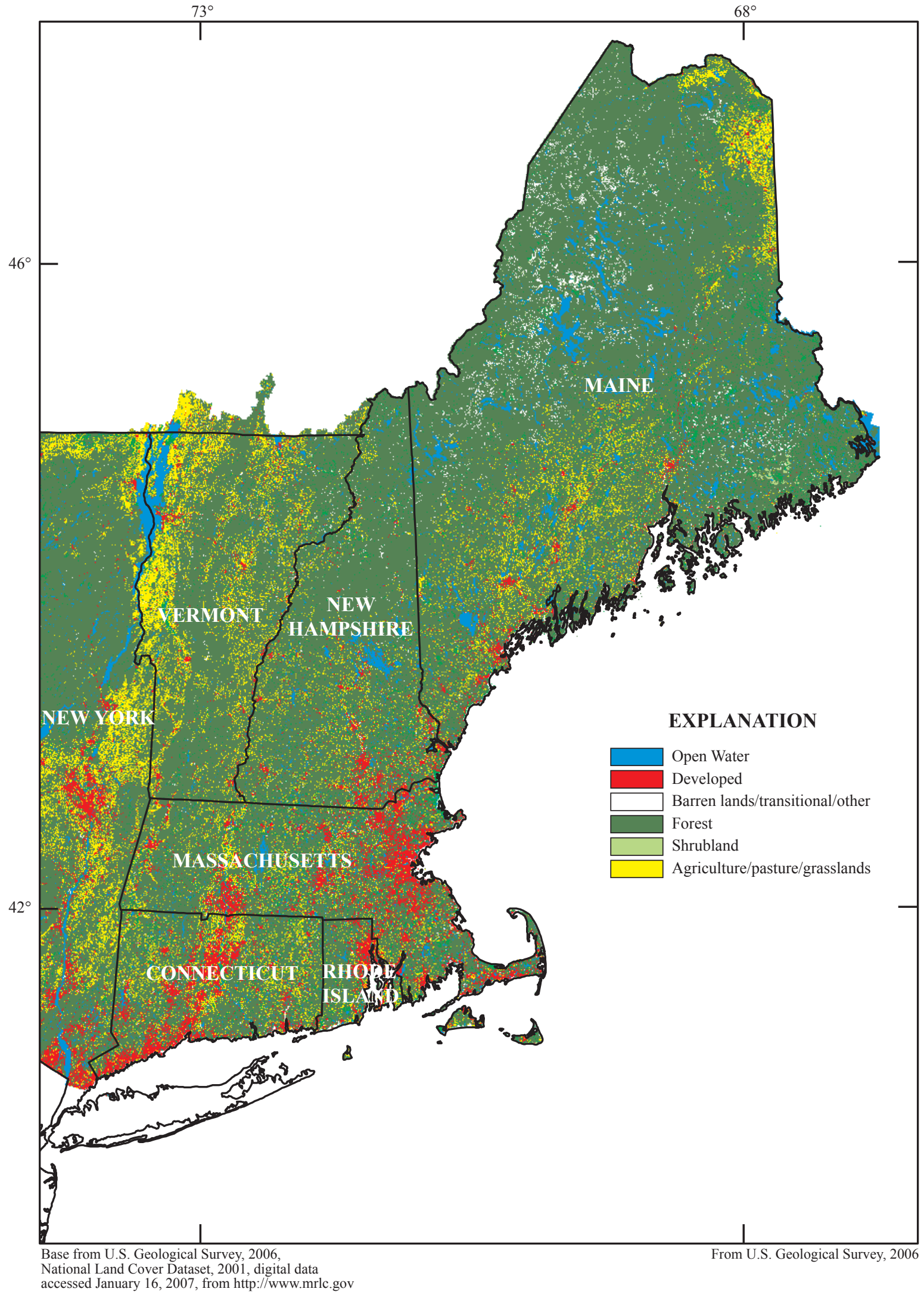

Figure 3. Land use patterns in the New England area. 
States is shown in Kontis and others (2004; fig. 2). High rates of runoff coincide with high topographic relief in areas of the Adirondacks, White Mountains, and northern Appalachians in Maine.

The NECRA are composed primarily of Proterozoic and Paleozoic igneous and metamorphic rocks (88 percent of the New England part of the aquifer). Major rock types also include variably deformed metasedimentary, metavolcanic, and plutonic rocks of various geologic ages and metamorphic grades (Robinson and Kapo, 2003). The most common crystalline igneous rocks are granite, rhyolite, diabase, pegmatite, and basalt (Sinnott, 1982). The most common metamorphic rocks are gneiss, schist, phyllite, slate, marble, quartzite, and argillite (Sinnott, 1982).

The NECRA are geologically complex with a structural fabric that generally trends northeast-southwest, perpendicular to the direction of collision during the Acadian Orogeny (Marvinney and Thompson, 2000). Lithologic and structural features of near-surface bedrock have been compiled from statewide maps of bedrock geology for Connecticut (Rogers, 1985), Maine (Osberg and others, 1985), Massachusetts (Zen and others, 1983), New Hampshire (Lyons and others, 1997), Rhode Island, (Hermes and others, 1994), and Vermont (Doll and others, 1961). The approximately 1,200 individual map units portrayed in these state bedrock-geology maps have been grouped into geologic provinces representing similar geologic setting and tectonic history (Robinson and Kapo, 2003). The province groups were defined with reference to lithostratigraphic explanations and correlation tables accompanying the state bedrock-geology maps (references above) and generally occur as north- to northeast-trending belts that follow the structural fabric of the Appalachian foldbelt and faults in New England (fig. 4). In the paragraphs that follow, the geologic-province categories are described in order of deformation or addition to North America (in the style of Cheney and Hepburn, 1993), generally from west to east across the New England States. These descriptions are based on information in Robinson and Kapo (2003).

The Grenville Belt province consists of Middle Proterozoic basement of the North American craton that was deformed and metamorphosed at high metamorphic grade during the Grenville orogeny approximately 1 billion years ago (fig. 4). Grenville Belt province rocks are exposed in areas of central Vermont, and western Massachusetts, and Connecticut. Some areas also were deformed, and retrograded, during younger orogenies.

The Eugeosynclinal Sequence province is mostly clastic and pelitic marine sedimentary rocks of Late Proterozoic to Ordovician age, including rift and arc volcanics and ultramafic blocks deposited in a continental slope or accretionary wedge
Table 1. Approximate land use distribution, by percent, in the New England crystalline rock aquifers.

\begin{tabular}{ccccc}
\hline \multicolumn{5}{c}{$\begin{array}{c}\text { Land-use distribution } \\
\text { (percent) }\end{array}$} \\
\hline Agricultural & $\begin{array}{c}\text { Urban } \\
\text { developed }\end{array}$ & Forest & $\begin{array}{c}\text { Surface } \\
\text { water }\end{array}$ & Other \\
\hline 6.6 & 8.1 & 60.6 & 12.8 & 11.9 \\
\hline
\end{tabular}

setting. These rocks were deformed primarily during the Taconian and Acadian orogenies and are metamorphosed from low to high grade.

The Waits River-Gile Mountain province consists of metamorphosed clastic, calcareous, and semipelitic marine rocks, with lesser volcanics of Cambrian to Devonian age. These rocks were deformed and metamorphosed during the Acadian orogeny.

The Bronson Hill Sequence province consists of metamorphosed volcanic-island-arc rocks, associated marine sediments of Cambrian to Ordovician age, and exotic Proterozoic basement deformed by the Taconian and Acadian orogenies. Locally, deformation also occurred in Connecticut during the Alleghanian orogeny.

The New Hampshire-Central Maine Sequence includes metamorphosed marine sedimentary rocks and volcanics of Cambrian to Devonian age. These rocks were deformed primarily during the Acadian orogeny.

The Coastal Maine province consists of Late Proterozoic to Silurian-Devonian volcanic and marine sedimentary rocks. These rocks were deformed and attached to North America during the Acadian orogeny and during the Alleghanian orogeny.

The Avalon Belt province includes granite and associated volcanic rock of Late Proterozoic age overlain by clastic continental platform and marine rocks with a fossil assemblage similar to West Africa. This province was deformed during the Alleghanian orogeny

The Narragansett Basin contains coarse to fine clastic sedimentary rocks deposited in basins that formed after attachment of the Avalon Belt province to North America. The basins were created, filled, and deformed during a transgressional phase of the Alleghanian orogeny. The rocks range from low to high metamorphic grade. 


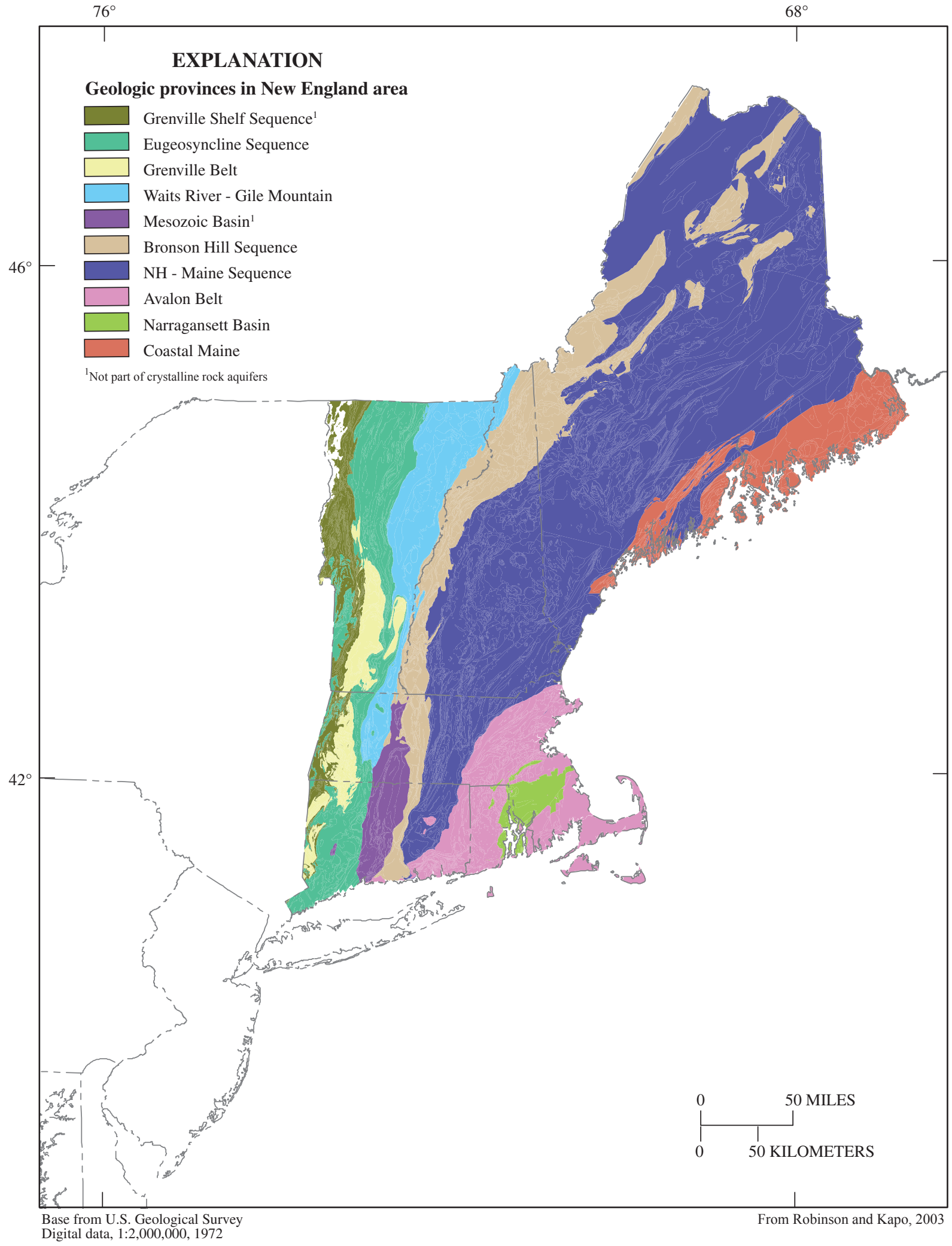

Figure 4. Geologic provinces in the New England crystalline rock aquifers. 


\section{Geohydrology}

Flow of water through the crystalline rocks is dependent on the presence of secondary openings. Spaces between the individual mineral crystals (primary openings) of the crystalline rocks are few, microscopically small, and generally unconnected. Consequently, the intergranular porosity of crystalline rocks is small, usually about 1 to 2 percent (Wood and others, 2004). Nonfractured sections of crystalline rocks have low hydraulic conductivity ranging from 0.000003 to $0.0001 \mathrm{ft} / \mathrm{d}$ (U.S. Geological Survey, 2003). For almost all wells completed in crystalline rocks, water reaches the wells through secondary openings other than intergranular pore spaces. Virtually all bulk movement of water in crystalline rocks is through fractures or joints in the rocks.

Fractures form in crystalline rocks as a result of the cooling and deformation of igneous and metamorphic rocks, faulting, jointing, and weathering. Openings commonly are present along relict bedding planes, cleavage planes, foliation, and other zones of weakness in the rocks; these openings typically are heterogeneous in spacing, orientation, size, and degree of interconnection. Generally, openings in the rocks are most prevalent near land surface and decrease in number and size with depth. Thus, wells in New England commonly are not drilled past depths of 300 to $600 \mathrm{ft}$ but some deeper wells have intersected deep water-yielding fractures. In a study evaluating bedrock yields in Massachusetts, bedrock yield was found to decrease with depth in the upper $400 \mathrm{ft}$ but some larger yields (median value greater than $20 \mathrm{gal} / \mathrm{min}$ ) were found at depths greater than $400 \mathrm{ft}$ (Hansen and Simcox, 1994). Deep wells (greater than $300 \mathrm{ft}$ ) installed in crystalline rock of the Blue Ridge Mountains adjacent to deep thrust faults have yielded several hundred gallons per minute of ground water (Seaton and Burbey, 2005).

The types of fractures in crystalline rock of the study area are similar to fractures in other geologic settings, in that highly permeable zones of subhorizontal fractures are embedded within a network of less permeable fractures (Shapiro, 2003). This highly variable pattern can be viewed as scale-dependent, where permeability variations decrease with increasing scale from the well field to watershed size.

Ground water in the upper $600 \mathrm{ft}$ of crystalline rocks is recharged from precipitation through the fracture system either directly at outcrop areas or indirectly through overlying glacial deposits (Harte, 1992). Recharge occurs primarily in the uplands (Harte, 1992); the water moves down a hydraulic gradient to stream valleys where it discharges either to the valley fill or to streams or other surface-water bodies, except where intercepted by ground-water withdrawals from wells. The rate of recharge to crystalline rock aquifers in the Mirror Lake area of New Hampshire was estimated to be 1-4 in/yr (Harte 1992; Tiedeman and others, 1998). Higher rates of recharge are possible in areas underlain by more fractured, permeable rock and where rates of ground-water withdrawals are high (exceeding $100 \mathrm{gal} / \mathrm{min}$ ) (T.J. Mack, U.S. Geological Survey, oral commun., 2007).
Although the crystalline rocks transmit water, the volume of water stored in the fracture system of these rocks generally is small, and drawdown is large in some pumped wells that produce only small quantities (less than $10 \mathrm{gal} / \mathrm{min}$ ) of water. Water that is stored in overlying glacial deposits or water in nearby streams or other surface-water bodies, however, commonly is hydraulically connected with the bedrock fracture system. This surficial water can provide large quantities of water as recharge to crystalline rock from inducement during pumping of wells completed in the crystalline rocks.

A summary of well characteristics for crystalline rock in New England as of 1985 is given in table 2. The typical range of well yields is less than $5 \mathrm{gal} / \mathrm{min}$, but yields from some wells may exceed $500 \mathrm{gal} / \mathrm{min}$. Recent trends (1994-2005) suggest wells have been drilled progressively deeper over time (Brandon Kernen, New Hampshire Department of Environmental Services, written commun., 2007).

In a study of bedrock wells in Massachusetts (Hansen and Simcox, 1994), a strong relation was found between well yields and topographic position. The median yield from wells in valleys and lowlands exceeded yields from hillside and hilltops by 25 to 100 percent. Furthermore, within valleys and lowlands, yields increased with increasing overburden thickness. In a study of well yields in central Vermont, well yields were highest in certain bedrock formations in lowlands (Kim and others, 2006). Similarly, bedrock type and topographic position explained 34 and 31 percent of observed variation in transmissivity, respectively, in Maine (Mabee, 1999). Mabee (1999) further identified the importance of regional geologic setting in controlling ground-water yield and suggested that bedrock type and topography may be more important attributes in controlling yield in the crystalline rock aquifers of New England than unglaciated areas underlain by crystalline rock in Maryland, and sedimentary rocks in Pennsylvania.

Table 2. Summary of well characteristics in crystalline rock aquifers in New England, by State.

[From U.S. Geological Survey, 1985; ft, feet; gal/min, gallons per minute; --, no information]

\begin{tabular}{|c|c|c|c|c|}
\hline \multirow{3}{*}{ State } & \multicolumn{4}{|c|}{ Well characteristics } \\
\hline & \multicolumn{2}{|c|}{ Depth (ft) } & \multicolumn{2}{|c|}{ Yield (gal/min) } \\
\hline & $\begin{array}{l}\text { Common } \\
\text { range }\end{array}$ & $\begin{array}{c}\text { May } \\
\text { exceed }\end{array}$ & $\begin{array}{l}\text { Common } \\
\text { range }\end{array}$ & $\begin{array}{c}\text { May } \\
\text { exceed }\end{array}$ \\
\hline Connecticut & $100-300$ & 500 & $1-25$ & 200 \\
\hline Maine & $20-800$ & -- & $2-10$ & 500 \\
\hline Massachusetts & $100-400$ & 1,000 & $1-20$ & 300 \\
\hline New Hampshire & $100-600$ & 800 & $1-10$ & 100 \\
\hline Rhode Island & $100-300$ & 500 & $1-20$ & 50 \\
\hline Vermont & $100-600$ & 800 & $1-10$ & 100 \\
\hline
\end{tabular}


A multidisciplinary geologic framework approach was used to evaluate ground-water yields in watersheds surrounding the southern Worcester Mountains in central Vermont (Kim and others, 2006). The Worcester Mountains are a north-northeast trending, south-plunging anticlinorial ridge with a core of resistant schist; this lithology forms the steepest slopes. The flanks and surrounding valleys are composed of generally less resistant amphibolites, phyllites, and granofels. Kim and others (2006) evaluated the relations between well yields and (1) lithologic and surficial units, (2) proximity to topographic lineaments, (3) surficial material thickness and permeability, (4) proximity to surface-water sources, (5) major bedrock structures, (6) slope and other topographic indices, and (7) drainage area. The two most significant variables that were found to correlate with well yield were bedrock lithology and topography.

In a regional study on bedrock well yield in New Hampshire, more than 400 explanatory variables were examined with respect to the natural $\log$ of the reported well yield ${ }^{1}$ by means of multivariate regression (Moore and others, 2002a, b). Results indicate that well yield is generally lower in wells on steep hill slopes and hilltops and at a greater distance from surface-water bodies. Yields were found to be greater in wells in valleys, at sites with large upgradient topographic drainage areas, and within $100 \mathrm{ft}$ of some types of mapped lineaments. Well yields also correlated with 29 mapped geologic units from the New Hampshire State Geologic Map (Lyons and others, 1997).

\section{Identification of Regional Water-Quality Issues}

Limited information is available on regional groundwater-quality patterns relative to hydrogeologic or land-use features other than summaries of ground-water constituent concentrations by major geologic unit (bedrock and unconsolidated), and geography (watershed and land use). Therefore, spatial trends for many regional water-quality constituents have not been identified.

Appendix 1 is a summary of contaminants as reported by State agencies in the New England area. This information was generated from reports (section 305(b) and section 303(d)) submitted by the States to the U.S. Environmental Protection Agency as required in the Clean Water Act. Ground-waterquality information largely is derived from water-quality tests by regulated community and non-transient public-watersupply systems that serve more than 25 people. The source of the water samples may be from a variety of measurement locations (for example, near the well or from the distribution system) and treatment options (treated and untreated water samples). Other regional water quality issues may be unreported and not reflected in the (section 305(b) and

\footnotetext{
${ }^{1}$ Although reported well yields from installation reports can provide an exaggerated well yield estimate because nonequilibrium conditions and borehole depletion are unaccounted for during testing, some general relations can be discerned from the large number of reported tests.
}

section 303(d)) reports. Thus, these data should be viewed only as a screening tool for identification of potential regional water-quality issues.

Natural contaminants, such as radon and heavy metals from minerals in the rock, were reported to have generally low concentrations in ground water in Rhode Island http://www.dem.ri.gov/pubs/305b/four.pdf and Vermont (Vermont Department of Environmental Conservation, 2004). In other states, little information exists on natural-contaminant occurrence as reported by State agencies. In New Hampshire, bedrock water quality is affected by high concentrations (above regulated limits) of fluoride, arsenic, and radioactive elements (appendix 1).

Anthropogenic contaminants such as bacteria, some volatile organic compounds (VOCs), and road deicers were detected in public-supply wells and monitoring networks in several states (appendix 1). Bacterial contamination in the form of total coliforms and Escherichia coli has been a particular problem in Vermont. Human and animal wastes are a primary source of bacteria in water and originate from feedlots, pastures, dog runs, urban and suburban yards, and other land areas where domestic-animal wastes are deposited, as well as forested and agricultural-edge areas where wild-animal wastes are deposited. Additional sources include seepage or discharge from septic tanks, sewage-treatment facilities, and natural soil/ plant bacteria. Bacteria from these sources can enter wells that are open at the land surface or do not have watertight casings or well caps http://www.water-research.net/bacteria.htm. Of the VOCs measured, MTBE was the most commonly detected in several states (appendix 1). Several states had no information on road-deicer-related chloride concentrations in ground water; where they were reported, as in Maine and Rhode Island, high sodium (greater than $100 \mathrm{mg} / \mathrm{L}$ ) and (or) chloride (greater than $250 \mathrm{mg} / \mathrm{L}$ ) concentrations were found in approximately 10 percent of public-supply wells (appendix 1).

A compilation of regional water-quality issues reported from the NAWQA study units (NECB, CONN, and LINJ) is provided in table 3 from sampled wells shown in figure 1. Water samples were analyzed for major ions, trace elements, pesticides, and VOCs. No biological (bacteria) analyses were done. VOCs were the most frequently detected anthropogenic class of contaminants whereas radon and arsenic were the most frequently detected natural contaminant as reported by NAWQA study units (table 3). High radon concentrations above the proposed MCL of $300 \mathrm{pCi} / \mathrm{L}$ (U.S. Environmental Protection Agency, 2006) were prevalent in samples from the NECB and CONN study units, indicating widespread detection of high radon in New England (Ayotte and others, 2007).

In crystalline rock aquifers in northern Europe (Norway and United Kingdom), natural contaminants with high concentrations include radon, fluoride, sodium, uranium, barium, iron, and manganese (Banks and others, 1998; Banks and Robins, 2002). The hydrogeologic environment in northern Europe is similar to that of New England, and northern European studies on regional water quality may provide insight into potential issues in New England. A Finnish study found 


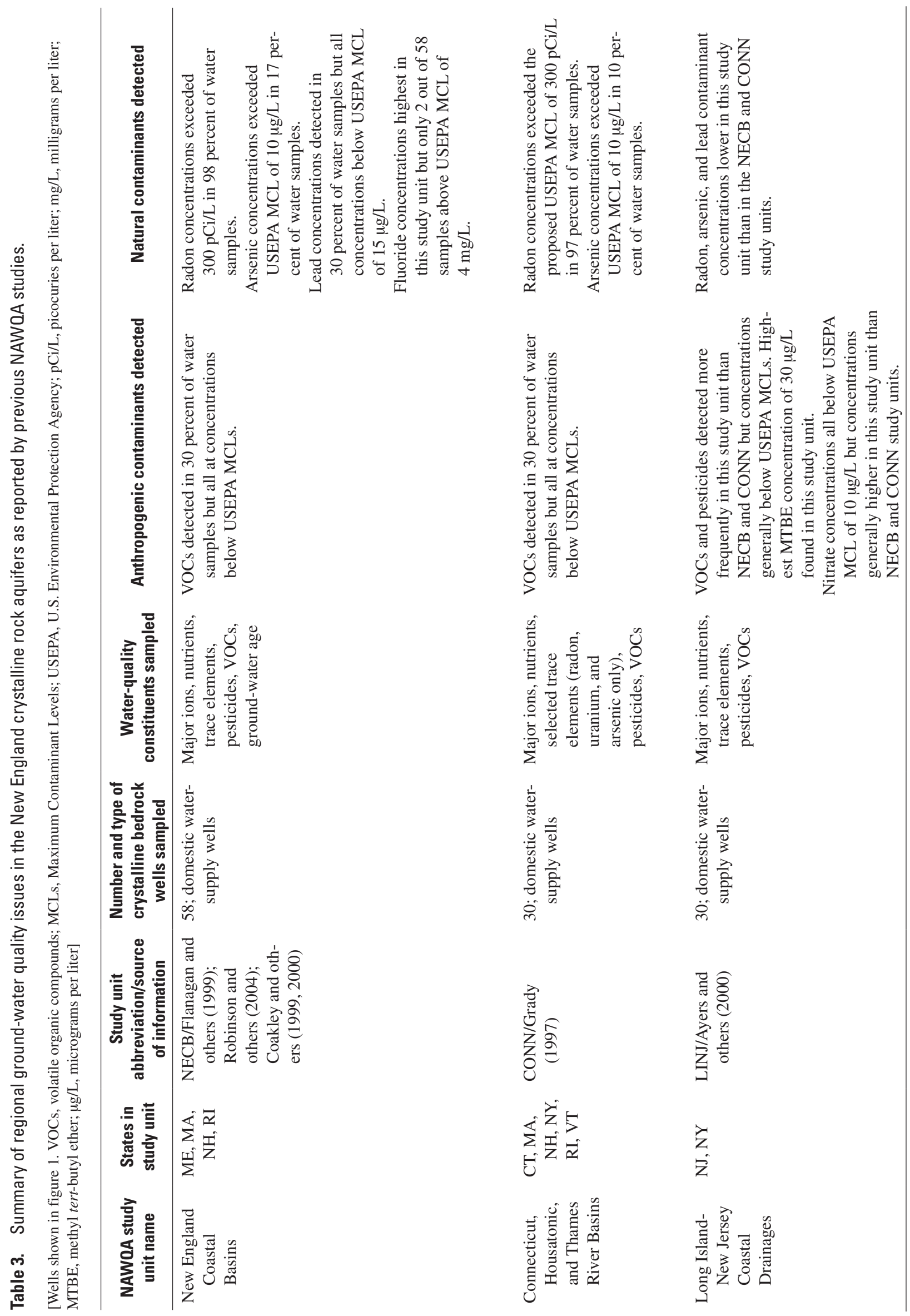


a strong correlation (Spearman's rho $=0.74, \mathrm{p}<0.0001$ ) between ${ }^{222}$ radon and ${ }^{210}$ lead in wells completed in crystalline aquifers (Vesterbacka, 2005; Vesterbacka and others, 2005). A similar contaminant relation between ${ }^{222}$ radon and total lead (rho $=0.52, \mathrm{p}=0.004$ ) was identified in domestic well samples from the granitic and metamorphic crystalline aquifers of the NECB study unit (fig. 1) in eastern New England (Ayotte and others, 2007).

\section{Factors Affecting Water Quality}

Factors and representative variables affecting water quality can be divided into two basic categories: physical and chemical. The division is arbitrary because physical and chemical processes are interdependent. For example, chemical reactions in ground water along fracture faces are partly a function of the reaction time of the ground water and the structure of the rock, which in turn are dependent on the physical characteristics of the rock, secondary fracture distribution, connectivity, aperture size, and the ground-waterflow field. The initial chemistry of the ground water may be related to the source of water; that is, whether it is recharged from overlying sediments, distant sources, or the atmosphere.

In a study of bedrock yield and ground-water quality in Maine, Mabee (1992) found that ground-water-flow processes in the bedrock affected ground-water quality. Ground-water quality correlated with bedrock type, topographic position, structural position relative to folds and faults, and the presence, thickness, and type of overlying unconsolidated deposits. For a constituent such as fluoride, for example, concentrations more highly correlated with the type and thickness of overlying unconsolidated deposits than with bedrock type suggest that ground-water recharge and the chemical quality of recharge water is an important explanatory variable.

\section{Physical Processes}

The small amount of storage and relatively high velocity (compared to porous media) of ground-water flow through fractures in crystalline rock may promote variable and potentially degraded ground-water quality. Therefore, the intrinsic susceptibility of the crystalline rock can be a major factor in occurrence of natural and anthropogenic contamination.

One example of degraded water quality because of low storage and high ground-water velocities is illustrated by a study of induced recharge caused by withdrawal of ground water in underlying fractured crystalline rock of a forested catchment area in Sweden. In this study, the induced recharge negatively effected ground-water quality in the crystalline rock by increasing vertical transport of shallow oxidized recharge water to the bedrock (Mossmark and others, 2007). The oxidized water altered the chemistry of the ground water in the crystalline rock. The withdrawals also caused increases in dissolved organic carbon and sulfate, thus, lowering the $\mathrm{pH}$ of the ground water. As a result, cations such as calcium, which were bound to bedrock fractures, became soluble in ground water.

Apparent residence times of ground water in fractured crystalline rock measured by age-dating tracers can vary due to mixing of ground water from different sources and, as noted above, the susceptibility to mixing is high given the low storage capacity and high velocity of flow in fractures. For example, in a study of fractured crystalline rock aquifers in Virginia, apparent residence times determined from environmental tracers (chloroflourocarbons (CFCs), tritium and tritium/helium, and sulfur hexafluoride $\left(\mathrm{SF}_{6}\right)$ ) in ground-water samples collected in bedrock wells showed a high percentage of young waters (less than 5 years old ) and high likelihood of a binary sample from mixing of young and old waters (Nelms and others, 2003). Further, the heterogeneous nature of fracture distributions and velocity fields results in a seemingly spatially random distribution of residence times. Nelms and others (2003) found that residence times of waters from crystalline rock did not correlate with total well depth.

CFC analysis and subsequent age-dating of ground-water samples collected in 58 domestic rock wells from crystalline rock aquifers as part of the NECB NAWQA study also showed no correlation with total well depth. The lack of correlation (Spearman correlation rho of 0.154) between total depth and apparent residence time is partly a function of several factors including (1) well-construction techniques in crystalline rock, (2) number of water-bearing fractures intersected by the borehole, (3) mixing of ground water outside of and inside of the borehole, (4) fracture connectivity of individual fractures, and (5) sampling method. For example, in domestic wells, which are actively withdrawing water, the ground-water sample represents an integrated water sample from the entire well borehole. The integrated water sample is derived from the flux-averaged contribution of the water-bearing capability of the individual fractures intersecting the well borehole (Shapiro, 2002).

Drilled wells in crystalline rock are generally constructed of long (median depth approximately $300 \mathrm{ft}$ ) open boreholes. In some cases, wells are drilled to a depth where enough fractures yielding sufficient supply are encountered. In other cases, wells may be drilled deeper to increase borehole storage. Even when a single fracture is intercepted by a well, variability in residence times can be large within a single fracture given that transport is controlled by fracture connectivity (intersection of other fractures with the single fracture). In some cases, mixing within a single fracture may exceed mixing in the borehole from multiple fractures if the fracture connectivity of the individual fracture is high. Cook and others (2005) conclude that residence times in low grade metamorphic fractured crystalline rock of Australia are controlled by the type and number of horizontal fractures intersecting the well borehole and the vertical connectivity of each horizontal fracture. Whereas the low grade metamorphic crystalline rock are characterized by planar fractures, which may not be applicable to the high grade metamorphic rock of New England, the conceptual analogy could be valid for the NECRA. 
A schematic diagram (fig. 5) illustrates the potential variability of residence time of ground water in crystalline rock from fracture patterns relative to depth-to-bottom of the well and length of open borehole. Two hypothetical end members are shown, the first from a relatively short open borehole (shallow depth) that is intersected by multiple horizontal fractures with little vertical connectivity (fig. 5A). The second from a long open borehole (deep well) that is intersected by few but vertically well-connected fractures (fig. 5B). The residence time and chemistry of ground water from these two end members can be quite different given the fracture distribution. The shallow well depicted (fig. 5A) can have residence times older than the deep well (fig. 5B) because the travel time within the horizontal fractures are greater than the travel times from the fractures connected vertically in the deep well. Associated with these fracture patterns are chemical differences in the ground water. If travel and reaction time are assumed equal, the shallow well depicted will have chemically more mature water than the deep well.

Although overall patterns in residence time of ground water are not readily discernible as a function of well depth, residence times correlate with variables that indirectly measure gross transport properties and infer residence time. For example, Ayotte and others (2003) found a positive correlation (Spearman correlation rho of 0.71) between $\mathrm{pH}$ and age of recharge water (fig. 6A). The $\mathrm{pH}$ of ground water in crystalline rock was hypothesized to be a surrogate for residence time because one of the primary factors affecting $\mathrm{pH}$, in addition to the amount of carbonate minerals, is hydrolysis of silicate minerals in crystalline rock. This reaction, which increases $\mathrm{pH}$, is a slow reaction so higher $\mathrm{pH}$ tends to indicate older ground water. The concentration of dissolved oxygen (D.O.) also was inversely correlated (Spearman correlation rho of -0.71) with apparent age (fig. 6B). The high D.O. concentrations in some crystalline rock aquifer ground-water samples suggest the possibility of relatively rapid recharge from overlying sources as the reason for young ground water. In contrast, high concentrations of arsenic are not directly related to the apparent residence time of the water (fig. 6C) (Ayotte and others, 2003). The relation of $\mathrm{pH}$ and dissolved oxygen to apparent ground water age is largely expected because these parameters are expected to be a function of ground water residence time. Thus, any mixing of waters of different ages is ultimately represented by the integrated water sample values for $\mathrm{pH}$ and dissolved oxygen.

The $\mathrm{pH}$ and dissolved oxygen of ground water is a good indicator of apparent ground-water age partly because of the ubiquitous nature of source inputs for these parameters in the NECRA. The inputs (dissolved oxygen and $\mathrm{pH}$ of recharge water) and processes affecting dissolved oxygen and $\mathrm{pH}$ are fairly uniform throughout the NECRA. While calcite concentrations may vary in certain rock types (Robinson and Kapo, 2003), which will affect $\mathrm{pH}$, the variability of calcite overall in the NECRA is small compared to the variability of trace elements such as arsenic.
Source input variability of arsenic or other similar trace element contaminants is high within the NECRA, thus their concentration is a poor indicator of apparent residence time (fig. 6C). For example, if arsenic in a well water sample from a deep well enters the well at some shallow depth, representing only a small fraction of the water entering the well, the concentration may not relate to the apparent age of the sample. Alternatively, if the source of arsenic in solution is desorption from iron oxides on the aquifer materials, there may be a threshold residence time that is coincident with iron reducing conditions and high arsenic concentrations. Further decreases in redox state, if associated with residence time, may not be related to further increases in arsenic concentration. Further, solute concentrations produced by a fracture source may vary due to the amount of arsenic available for desorption, irrespective of apparent residence time.

Occurrence of anthropogenic contaminants in ground water in crystalline rock is affected by the physical processes of vertical flow, recharge, dilution, and reactive and nonreactive chemical transport. Anthropogenic contaminants are often closely related to land use and recharge waters because these contaminants require external source inputs to the aquifer and include VOCs, such as MTBE and chloroform; road-deicing chemicals; pesticides; and nitrate (Gilliom and others, 2007; Zogorski and others, 2006; Ayotte and others, 2008).

MTBE concentrations in samples from private bedrock wells in New Hampshire and Maine have been related to several urban factors including population density, housing density, and the percentages of urban land use and roads within 1,640 ft (500 m) of the well (State of Maine, 1998; Ayotte and others, 2004). MTBE concentrations, for example, declined with increasing distance from underground gasoline storage tanks. In addition, MTBE concentrations were related to the specific conductance of the water sample. Because specific conductance may increase in response to chloride from road deicers and septic systems, it also is an indicator of urbanization. MTBE concentrations were significantly higher in water samples that were more acidic (lower $\mathrm{pH}$ ). The implication is that recently recharged (low $\mathrm{pH}$ ) ground water is more directly connected to the land surface and, thus, to sources of MTBE. Conversely, ground water with high $\mathrm{pH}$ may be relatively old and, in some cases, could predate the introduction of MTBE into the local ground-water system (Ayotte and others, 2004).

MTBE concentrations positively correlated with increasing depth of wells (Ayotte and others, 2004). Given drilling practices in the bedrock, deep wells in some cases indicate insufficient or low yield because long open holes are required to provide adequate storage for water supply. Consequently, deep wells are generally low yielding, and the high occurrence rates and concentrations of MTBE in deep wells could result from several processes. For example, in low-yield wells, a major proportion of the water and MTBE contamination may be derived from leakage of shallow ground water, either through fractures near the bedrock surface or along the well casing, because insufficient yield is provided in 


\section{A Shallow well}

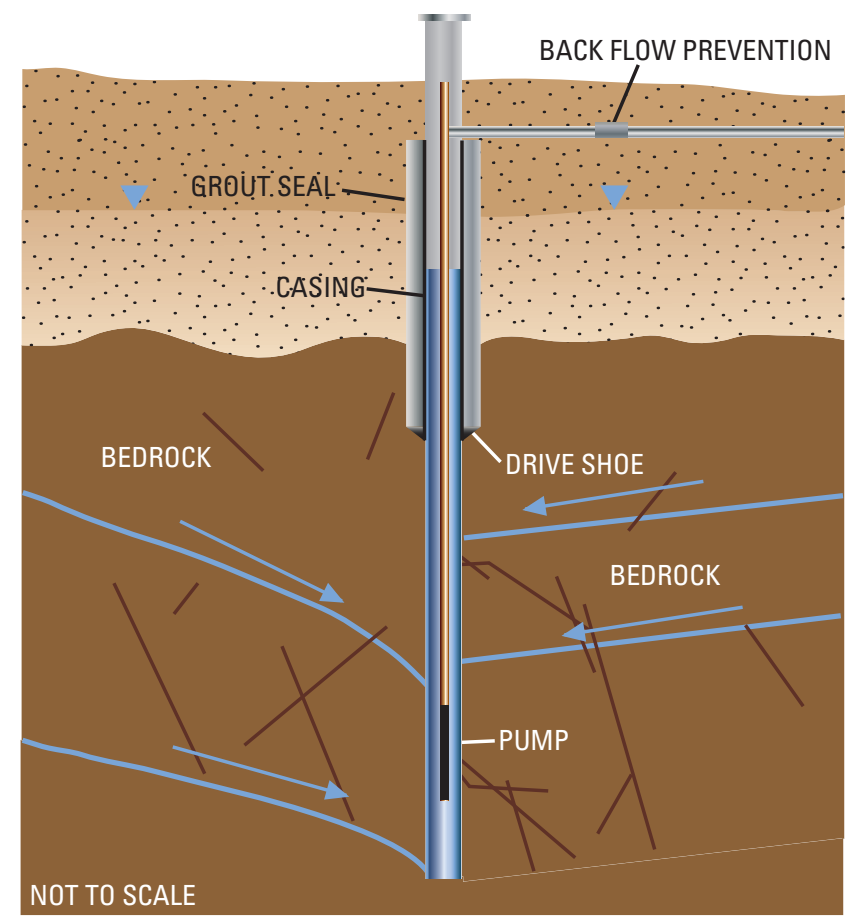

Shallow well with multiple horizontal fractures

\section{EXPLANATION}

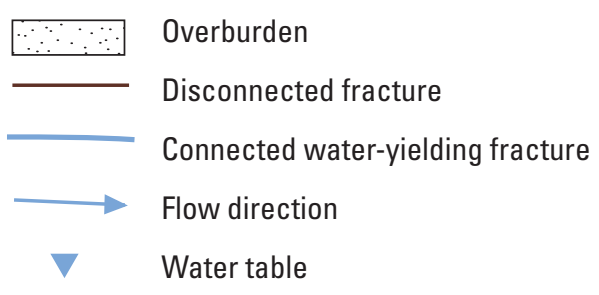

B Deep well

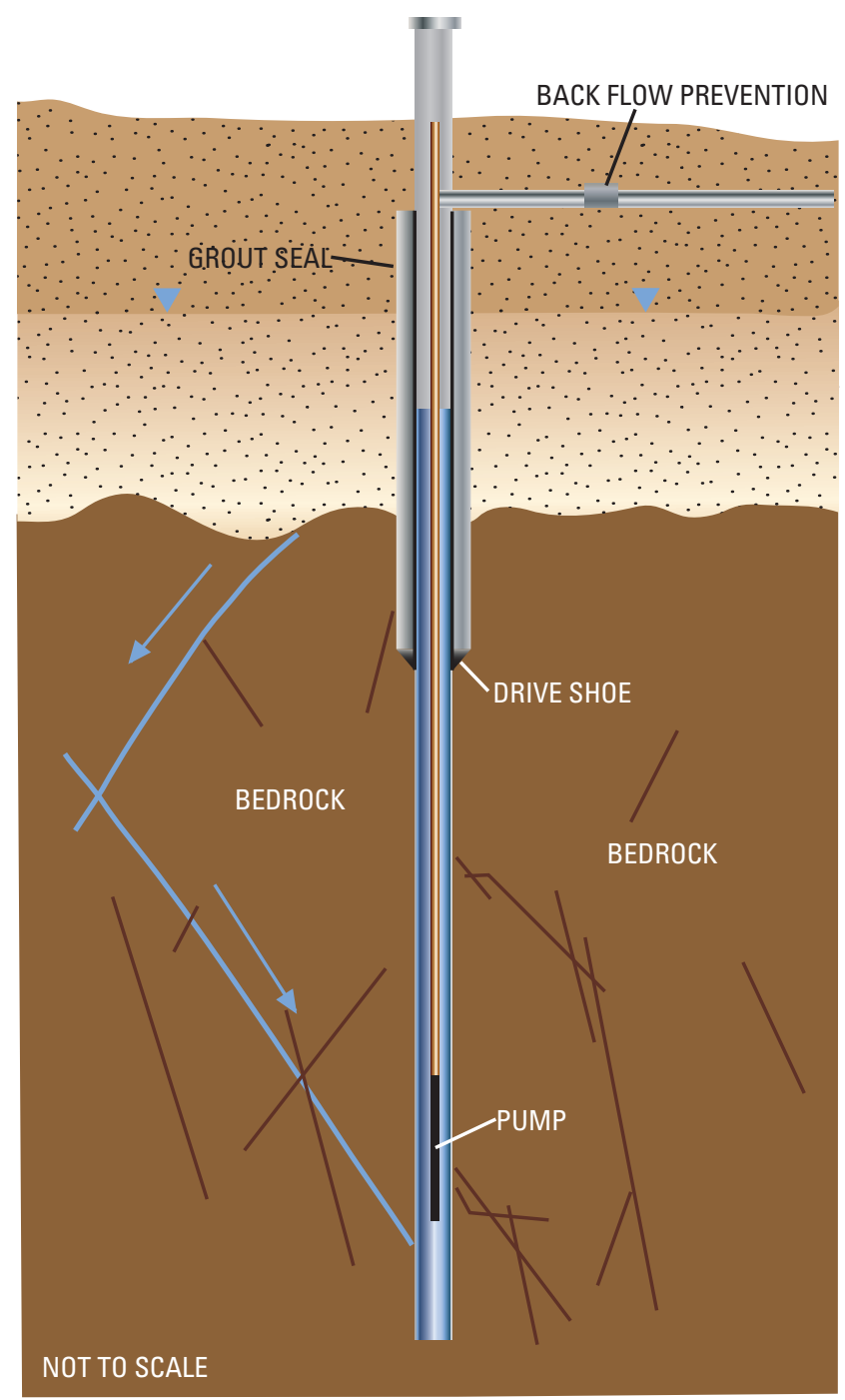

Deep well with few vertical fractures

Figure 5. Hypothetical depth of well and fracture patterns in (A) shallow wells and $(B)$ deep wells in the New England crystalline rock aquifers. 
$\boldsymbol{A}$
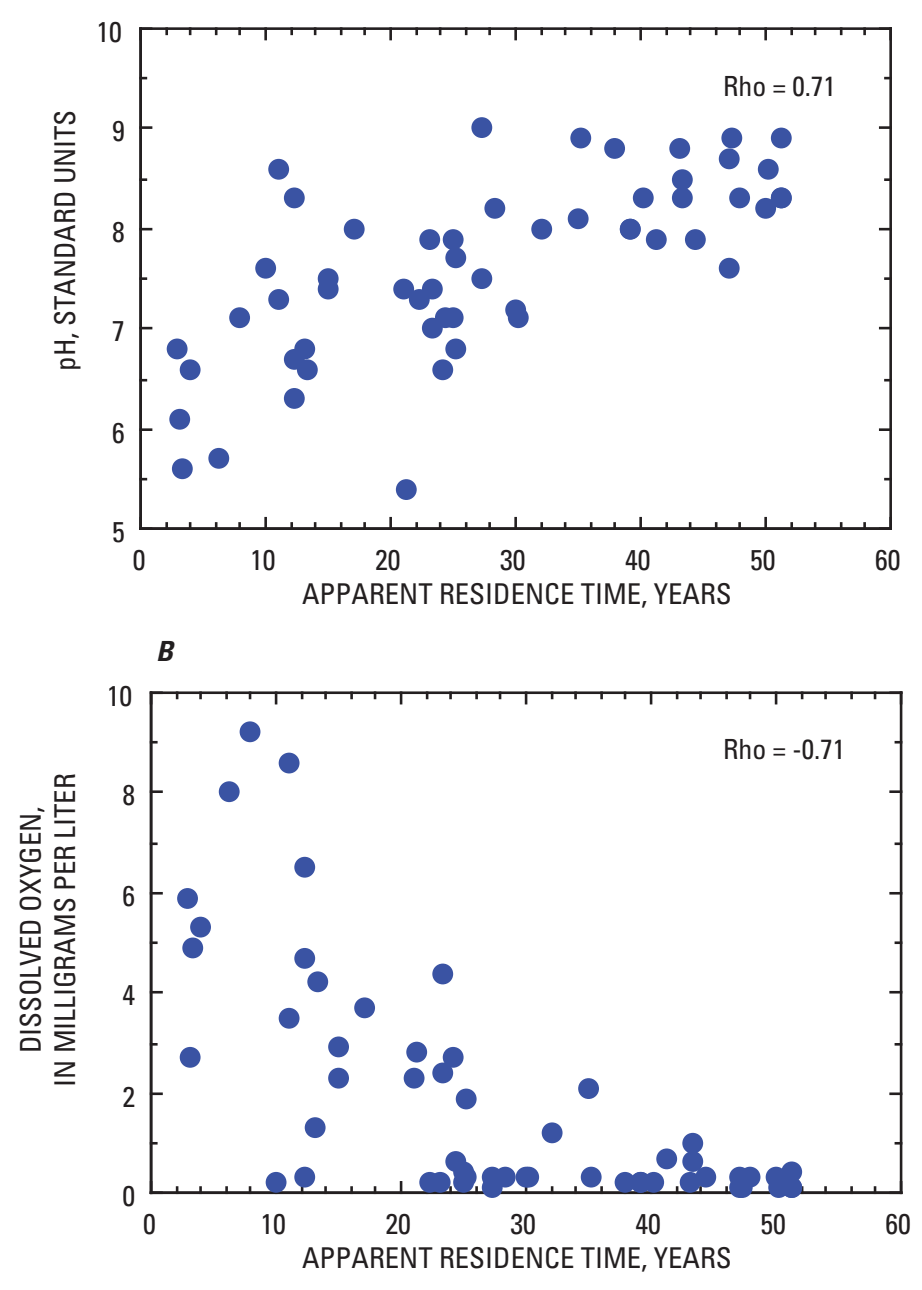

$c$

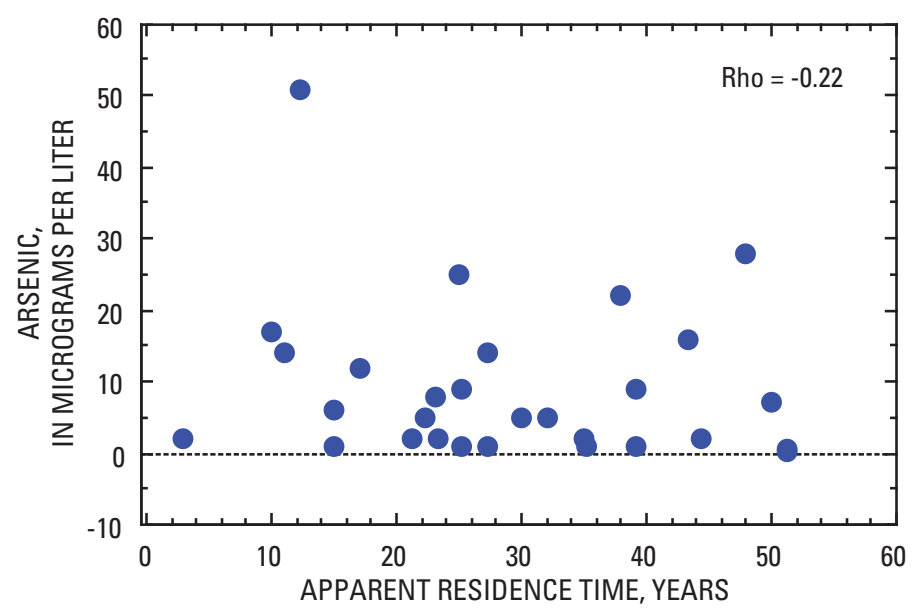

Figure 6. Relation between residence time and $(A) \mathrm{pH}$, $(B)$ dissolved oxygen, and $(C)$ arsenic from crystalline rock ground water of the New England Coastal Basins. (From data presented by Ayotte and others, 2003) the deeper bedrock. Alternatively, low-yield wells with little or no surface leakage may be less affected by dilution. Einarson and Mackay (2001) indicate that contaminant concentrations in wells under constant pumping decrease with increasing pumping rate because the ratio of clean water to contaminated water increases. Thus, for deep, low-yield bedrock wells, MTBE that enters the well is less likely to be diluted than in high-yield wells.

The relation between vertical fracture patterns in the bedrock and the geohydrologic characteristics of the overburden is an important factor in crystalline-rock yield and ground-water quality. Lyford and Walsh (2004) showed that high-angle vertical fracturing facilitated vertical flow from the overburden and that this condition enhanced well yield from crystalline rock at several sites in Massachusetts where overburden was thick. In addition to yield, increased vertical flow can enhance vertical transport. Contiguous vertical fractures have been shown to facilitate nitrate transport (Taylor and others, 2001) in crystalline rock. For example, nitrate concentrations in ground-water samples from vertical fractures intersecting the Metrowest Water Supply Tunnel in Boston were highest in areas underlying a pond, suggesting vertical recharge from the pond and transport of nitrate.

\section{Chemical Processes}

Bedrock lithology and the chemistry and mineralogy of the host rock material are important factors in bedrock water quality. For example, regional assessments of arsenic concentrations in crystalline rock of New England have identified lithology as an important explanatory variable in predicting arsenic concentrations (Ayotte and others, 2006). High arsenic concentrations have been associated with a lithostratigraphic belt of calcareous metasedimentary rocks (Ayotte and others, 1999). These rocks contain higher arsenic concentrations (median value $>1 \mathrm{mg} / \mathrm{kg}$ ) in whole-rock samples than some other rock types in the region (Robinson and Ayotte, 2006). Felsic volcanic rocks and sulfidic metamorphic rock types sampled by Robinson and Ayotte (2006) also had elevated whole-rock arsenic concentrations.

The solubility and mobility of chemicals in source parent material depend on geochemical conditions $(\mathrm{pH}$, redox, and activity coefficient) and transport mechanisms. For example, arsenic concentrations in ground water in the crystalline rock tend to correlate with certain $\mathrm{pH}$, Eh, and dissolved oxygen levels. High arsenic concentrations $(>10 \mu \mathrm{g} / \mathrm{L})$ generally corresponded to high $\mathrm{pH}(7.0-8.5)$ in ground-water samples from crystalline rock of New England (Ayotte and others, 2003). Furthermore, high arsenic concentrations were associated with low dissolved oxygen concentrations $(<1 \mathrm{mg} / \mathrm{L})$. Aqueous arsenic in ground water exists primarily as the oxyanions arsenate $\left(\mathrm{AS}^{5+}\right)$ and arsenite $\left(\mathrm{AS}^{3+}\right)$. Arsenate predominates in oxic waters whereas arsenite is in sulfidic and methanic waters (Welch and others, 2000). Arsenic desorbs from iron hydroxyoxides and some clays at high $\mathrm{pH}$; thus, desorption 
may be an important mechanism leading to elevated arsenic concentrations in ground water (Welch and others, 2000). Arsenic associated with sulfide minerals in rock can be released by the weathering effects of oxygen-rich environments, whereas arsenic bound to iron oxides can be released by iron-reducing bacteria in low-oxygen conditions.

In addition to geochemical conditions, dissolved organic carbon can affect arsenic concentrations because of its control on redox state. Landfill leachate with low dissolved-oxygen concentrations $(<1 \mathrm{mg} / \mathrm{L})$ has been shown to facilitate reductive dissolution of hydrous ferric oxides and associated arsenic (Stollenwerk and Colman, 2004).

Microbial conditions can indirectly and directly affect arsenic concentrations. Available dissolved oxygen will enhance microbial activity, resulting in lowering redox potential and subsequent release of arsenate via reductive dissolution. During microbial arsenate respiration, arsenate is reduced to arsenite by arsenate reductase (Oremland and Stolz, 2003).

Whereas bulk movement of ground water relies on flow through secondary openings, ground-water chemistry can be affected by interaction of water with the rock matrix through rock-matrix diffusion. Matrix diffusion was hypothesized to affect ${ }^{222}$ radon concentrations in crystalline rock at the Mirror Lake research site in New Hampshire by diffusion of parent compound, radium ${ }^{226}$, through the rock matrix and accumulation onto weathered fracture faces (Wood and others, 2004). Thus, water-rock chemistry can be affected by a combination of rock-matrix diffusion and fracture-face weathering.

Ground-water quality may be influenced by regional and local bedrock structure and mineral segregation that develop in response to stress-strain fields. For example, structural features in a given rock can affect flow patterns and rates, residence time, and dilution. From a chemical standpoint, rock deformation can produce mineral segregations that are preferentially located along structural features, such as faults, shear zones, and fractures. These mineral segregations can influence water chemistry through secondary mineral precipitation, enhanced weathering, and chemical exchange reactions during water-rock interactions. For example, shear zones that form mylonites sometimes have bulk compositions that differ from the unsheared rock (Veeger and Ruderman, 1998). Ground water from shear zones can have elevated arsenic concentrations relative to ground water from similar unsheared rock (Veeger and Ruderman, 1998).

\section{Considerations for Development of Regional Framework}

This report considers studies that investigate yield and water quality because of the relation between ground-waterflow characteristics and water quality. Specifically, flow in crystalline rock affects residence time, recharge, dilution, and mixing of ground water and therefore, flow can affect water quality.
A common theme in the characterization of regional variability of natural contaminants in crystalline rock aquifers of New England is the importance of the mineralogic and lithologic composition of the rock type (table 4, in back of report). This appears to be a primary explanatory variable in most studies. However, geologic structure and fracture patterns have been shown to control ground-water flow and therefore, transport processes related to flow such as dilution, and the chemical composition of the rock through mineralogic segregation along structural features (Veeger and Ruderman, 1998). For anthropogenic and natural contaminants, groundwater flow, geochemistry, and land use are all important influences (table 4, in back of report). Although the source of contaminant is from near-surface inputs for anthropogenic contaminants, natural sources or contaminants indigenous to the rock and soil may also be affected by geochemical processes induced from anthropogenic practices.

\section{Review of Other Framework Approaches}

Lapham (1990) proposed an approach to characterize the hydrogeologic framework for the bedrock of New England (fig. 7) and the comparison of features such as water quality to the framework. As stated by Lapham (1990), "Characterization of the bedrock framework consists of a description of the following physical properties of the rock: (1) the primary porosity of the rock; (2) the types of rock fracture systems (joints, faults, shear zones) that contribute to the rock's secondary porosity; and (3) the characteristics of these fracture systems, including the areal and vertical geometry, orientation, size of openings, spacing, density, and fracture interconnection." Lithologies in geologic provinces with differing geologic, tectonic, and deformation histories may develop different patterns of fault and fracture systems in response to differing stress regimes. As such, hydrologic properties may differ based on lithology, geologic province, or terrane features.

Regional analysis of anthropogenic contamination from nitrogen loading (fertilizer land application and sewage) have been studied primarily for areas dominated by contiguous (areally extensive) surficial aquifers (Navulur and Engel, 1998) as well as other areas of the United States (Lindsey and others, 2006). These regional studies provide insight into how one might apply similar methods to understand the occurrence of anthropogenic contaminants in crystalline rock aquifers.

The vulnerability of ground-water systems in Indiana to nitrate contamination was assessed by use of soil information from the National Resources Conservation Service (NRCS) State Soil Geographic database (STATSGO) (Navulur and Engel, 1998). This information proved useful in predicting areas of elevated nitrate concentrations and the regional distribution of nitrate in ground water. Vulnerability was further assessed by use of the U.S. Environmental Protection Agency model DRASTIC (Aller and others, 1987), which characterizes hydrogeologic settings based on features that control ground-water flow, including depth to water, net recharge, 


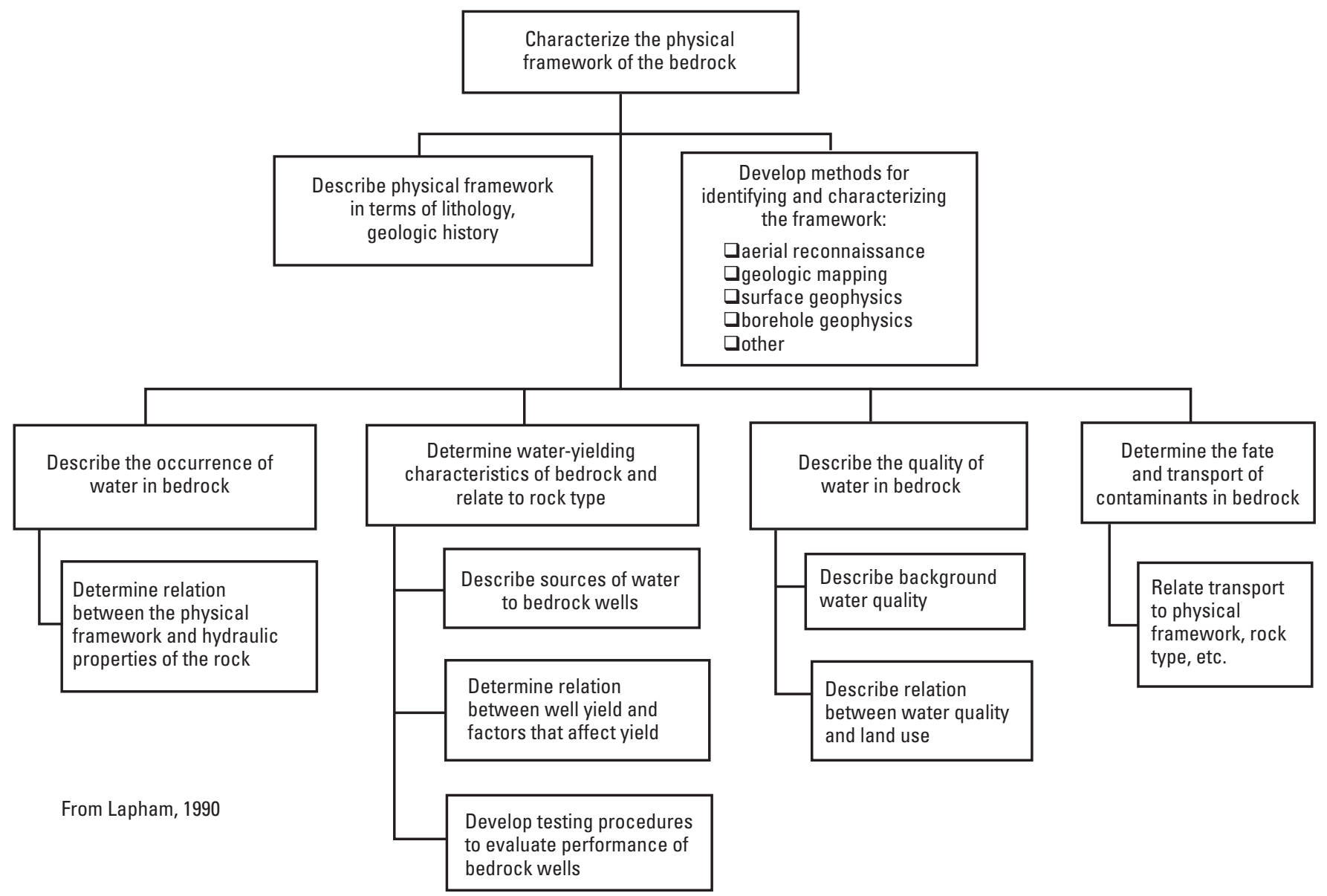

Figure 7. Objectives from a proposed 1990 study of the hydrogeology of bedrock of New England. 
aquifer media, soil media, topography, impact of the vadosezone media, and hydraulic conductivity of the underlying aquifer. The vulnerability of the aquifer to contamination can then be spatially mapped with the DRASTIC model. Navulur and Engel (1998) showed that this approach was effective in identifying areas of nitrate contamination in Indiana. Eightyone percent of nitrate detections in Indiana occurred within the area ranked most vulnerable to contamination although the land area represented only 25 percent of the State.

Nonlinear-regression models have been developed to assess nitrate concentrations across the United States, including crystalline rock aquifers of the New England area (Nolan and Hitt, 2006). A mechanistic structure was applied in model development that segregates nitrogen sources and physical factors that enhance or restrict nitrate transport in ground water. Results indicate that areas with high nitrogen application, high recharge, well-drained soils, fractured rocks or aquifers with high effective porosity, and lack of attenuation processes have the highest predicted nitrate concentration.

Crystalline rock aquifers in the southern Appalachian Mountains (Lindsey and others, 2006) were examined for selected contaminants including nitrate, pesticides, volatile organic compounds (VOCs), and radon. Linear regression and logistic regression models were developed to identify variables important in estimating concentrations. For nitrate, the percentage of agricultural land use, the input of nitrogen from all sources, and dissolved oxygen were the most significant variables affecting increased concentrations of nitrate. For VOCs, detections were related to land use and well depth. The analysis indicated a significant positive correlation between chloroform concentration and urban land use, leaking underground storage tanks, and population density. MTBE concentrations also were positively correlated to the same variables. Both chloroform and MTBE were inversely related to well depth and shallower wells had higher concentrations than studies in New England (Ayotte and others, 2004) that show a positive correlation with well depth. These differences in results point to potential variations in source input and flow processes between crystalline rock in the New England region and elsewhere. For ${ }^{222}$ radon, crystalline rock aquifers with felsic mineralogy had the highest concentrations, and the lowest concentrations were in areas with mafic mineralogy.

MTBE concentrations in public- and private-supply wells in crystalline rock aquifers of New Hampshire were analyzed by use of logistic regression models (Ayotte and others, 2008). Important variables in predicting concentrations included source terms (distance from potential fuel sources) as well as certain variables related to transport and dilution. Proxy variables such as low $\mathrm{pH}$ correlated with MTBE concentrations suggesting residence time is an important variable, with low $\mathrm{pH}$ indicative of young immature waters.

Assessments of regional ground-water quality in fractured crystalline rock of New England have utilized the lithochemical approach developed by Robinson (1997). This approach is predicated on the relation that the general reactivity of the crystalline rock controls regional ground-water qual- ity patterns. The lithochemical approach has been shown to be a powerful tool in evaluating regional ground-water quality for some common ( $\mathrm{pH}$, hardness, iron, manganese, fluoride, arsenic, and radon) water-quality constituents (Moore, 2004) and for specific trace constituents such as arsenic (Ayotte and others, 1999, 2003, 2006; Robinson and Ayotte, 2006). The rock types in the crystalline rock aquifers of New England have been categorized into lithology groups that likely have similar effects on ground-water quality (Robinson, 1997). These characteristics are based on mineralogical and chemical characteristics relevant to water quality, which include the reactivity of constituent minerals to dissolution and the presence of carbonate or sulfide minerals (Robinson and others, 2002; Montgomery and others, 2002). When integrated with landscape variables, the lithochemical approach can be used to evaluate regional ground-water quality for a variety of natural and anthropogenic contaminants (Ayotte and others, 1999, 2003, 2006; Robinson and Ayotte, 2006).

The lithochemical classification (groups) for the New England part of the NECRA is shown in figures 8 and 9. The rock groups are derived from rock group categories A and B as reported in Robinson and Kapo (2003). Lithochemical classification is unavailable for the New York and New Jersey part of the NECRA.

The general lithology groups shown in figure 8 are (1) calcareous rock types containing carbonate minerals (Carbonate rocks and Calcpelite), (2) mafic rock types with abundant ferromagnesian and calcsilicate minerals (Mafic rocks), (3) granitic rock types predominantly made up of alkali feldspar and quartz (Granite rocks), and (4) other metamorphic rock types that include subgroups such as sulfidic schists and dominantly pelitic (mica-rich) metasedimentary rocks (Metamorphic rocks, undivided). In figure 8, the granitic and metamorphic rock categories in rock group $\mathrm{A}$ are subdivided into additional subcategories based on general differences in mineralogy and (or) rock geochemistry.

As is evident in figures 8 and 9 , the lithologic framework of the New England part of the NECRA is heterogeneous and complex. Table 5 lists the area fractions of the various lithology groups in the New England part of the NECRA.

Ground-water flow characteristics of the fractured crystalline rock have been noted as a potentially important factor in the assessment of regional water quality and techniques that can discern regional patterns in flow should be considered as part of the framework approach. Ground-water flow characteristics of parts of the fractured crystalline rock of New England area have been examined by use of the hydrostructural domain approach (Mabee and Kopera, 2005; Manda and others, 2005, 2006). This approach maps rocks based on hydrostructural domains, which are regionally grouped physical attributes including rock type, number and distribution of fracture sets, type of fractures present or absent, degree of fracture development, fracture spacing, and nature of fracture termination (Manda and others, 2006). Together with the surficial geologic setting (overburden characteristics), the hydrostructural domain controls ground-water flow and source of water to 


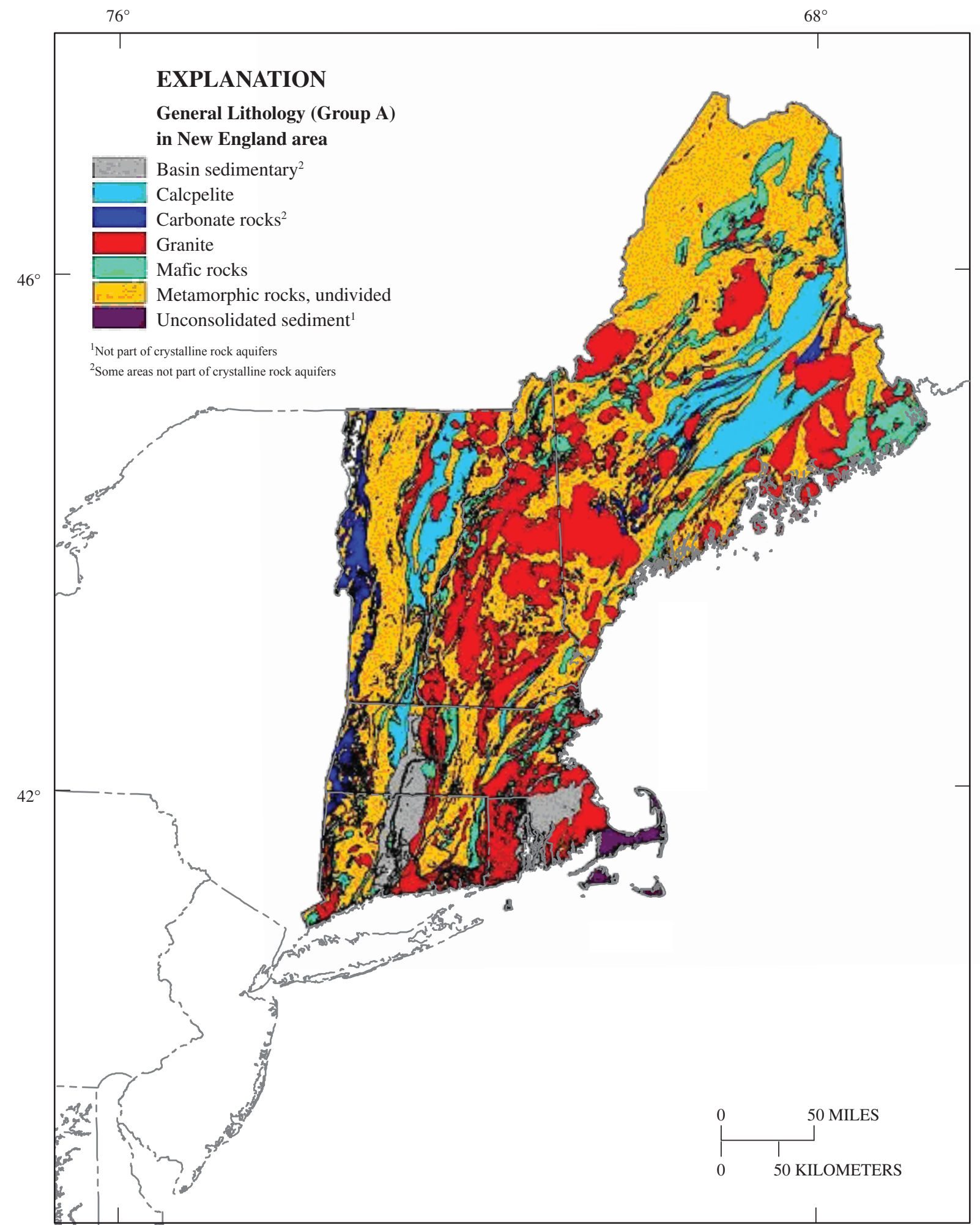

Base from U.S. Geological Survey Digital data, 1:2,000,000, 1972

Figure 8. General lithology distribution of rock group A in the New England crystalline rock aquifers. 


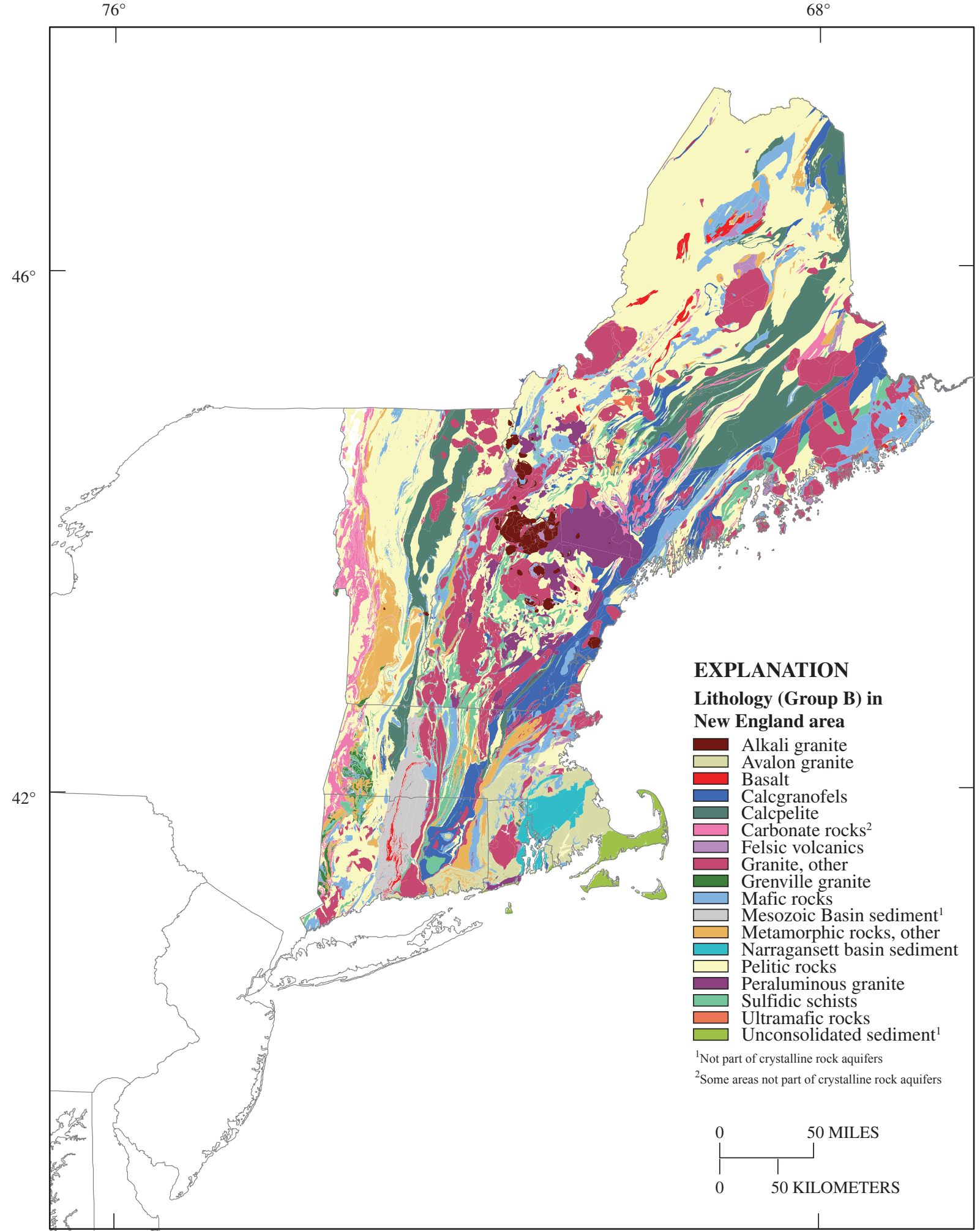

Base from U.S. Geological Survey Digital data, 1:2,000,000, 1972

From Robinson and Kapo, 2003

Figure 9. Lithology distribution of rock group B in the New England crystalline rock aquifers. 
Table 5. Lithology groups and their respective area fractions for the New England crystalline rock aquifers.

[Rounding in area fraction may not add up to 1.0]

\begin{tabular}{|c|c|c|c|}
\hline Lithology group A & Area fraction & Lithology group B & Area fraction \\
\hline \multirow[t]{2}{*}{ Mafic rocks } & 0.085 & Mafic rocks & 0.084 \\
\hline & & Ultramafic rocks & .001 \\
\hline \multirow[t]{6}{*}{ Granite } & .253 & Alkali granite & .013 \\
\hline & & Peraluminous granite & .036 \\
\hline & & Avalon granite & .031 \\
\hline & & Grenville granite & .004 \\
\hline & & Granite, other & .160 \\
\hline & & Felsic volcanics & .009 \\
\hline Calcpelite & .095 & Calcpelite & .095 \\
\hline \multirow[t]{4}{*}{ Metamorphic rocks, undivided } & .521 & Calcgranofels & .068 \\
\hline & & Pelitic rocks & .368 \\
\hline & & Sulfidic schists & .041 \\
\hline & & Metamorphic rocks, other & .044 \\
\hline Basin metasedimentary & .013 & Narragansett Basin & .013 \\
\hline
\end{tabular}

crystalline rock aquifers. Conceptually, in its simplest explanation, the physical characteristics of the fractured rock impart preferred flow patterns. For example, regions with units of rocks that have only one fracture-set orientation will exhibit anisotropic flow trending parallel to the strike set.

Areas of potential enhanced vertical flow and transport can be ascertained from the hydrostructural domain approach. Conversely, areas with primarily horizontal sheeting fractures have less vertical flow and dilution from the overburden (Lyford and Walsh, 2004); these areas also can be identified. In particular, foliated rock with fractures parallel to foliation exhibit high connectivity and enhanced rates of ground-water recharge (Manda and others, 2007). Thus, these rocks may have identifiable patterns of ground-water quality due to dilution, recharge, and vertical transport of contaminants.

\section{Discussion of Regional Framework Factors}

A framework for analysis of water quality across the NECRA consists of a group of spatial variables representing features related to aquifer properties, hydrologic conditions, and contaminant sources. These variables can be used in varying combinations (depending on the contaminant) to categorize the aquifer region into areas of similar hydrogeologic characteristics to evaluate variation in water quality. For consideration as a spatial variable, information must be available across the study area, such as degree of rock foliation.

The framework includes variables grouped under four categories (features; table 6) that can be mapped over the aquifer. The categories are (1) geologic, (2) geochemical, (3) hydrophysiographic, and (4) land use-land cover spatial features. On a regional scale, these features represent indicators of natural and anthropogenic sources of contaminants, as well as generalized physical characteristics of the aquifer system that influence ground-water chemistry and flow. The incorporation of these features into a regional evaluation will help characterize this large region into areas of similar hydrologic characteristics and contaminant sources in which water quality can be compared. Variables associated with these features, sources of information, and proposed contaminants to be evaluated for this study are listed in table 6 .

Contaminant chemistry in crystalline-rock ground water also depends on source inputs of contaminants (types of contaminants and water chemistry), aquifer 
Table 6. Categories of spatial features, associated explanatory variables, sources of information, and ground-water contaminants to be evaluated for the regional study of the New England crystalline rock aquifers.

[MTBE, methyl tert-butyl ether; $\mathrm{NaCl}$, sodium chloride; N, nitrogen; As, arsenic; U, uranium; Ra, radium; Rn, radon; STATSGO, State Soil Geographic Database (Source of data is at Oregon State University in Corvallis, Oreg., at http//www.ocs.oregonstate.edu/prism/index.phtml); PRISM, Parameter-elevation Regressions on Independent Slopes Model climate mapping system; USGS, U.S. Geological Survey; NLCD, National Land Cover Data; TIGER, Topologically Integrated Geographic Encoding and Referencing; salt refers to sodium, chloride and trace contaminants]

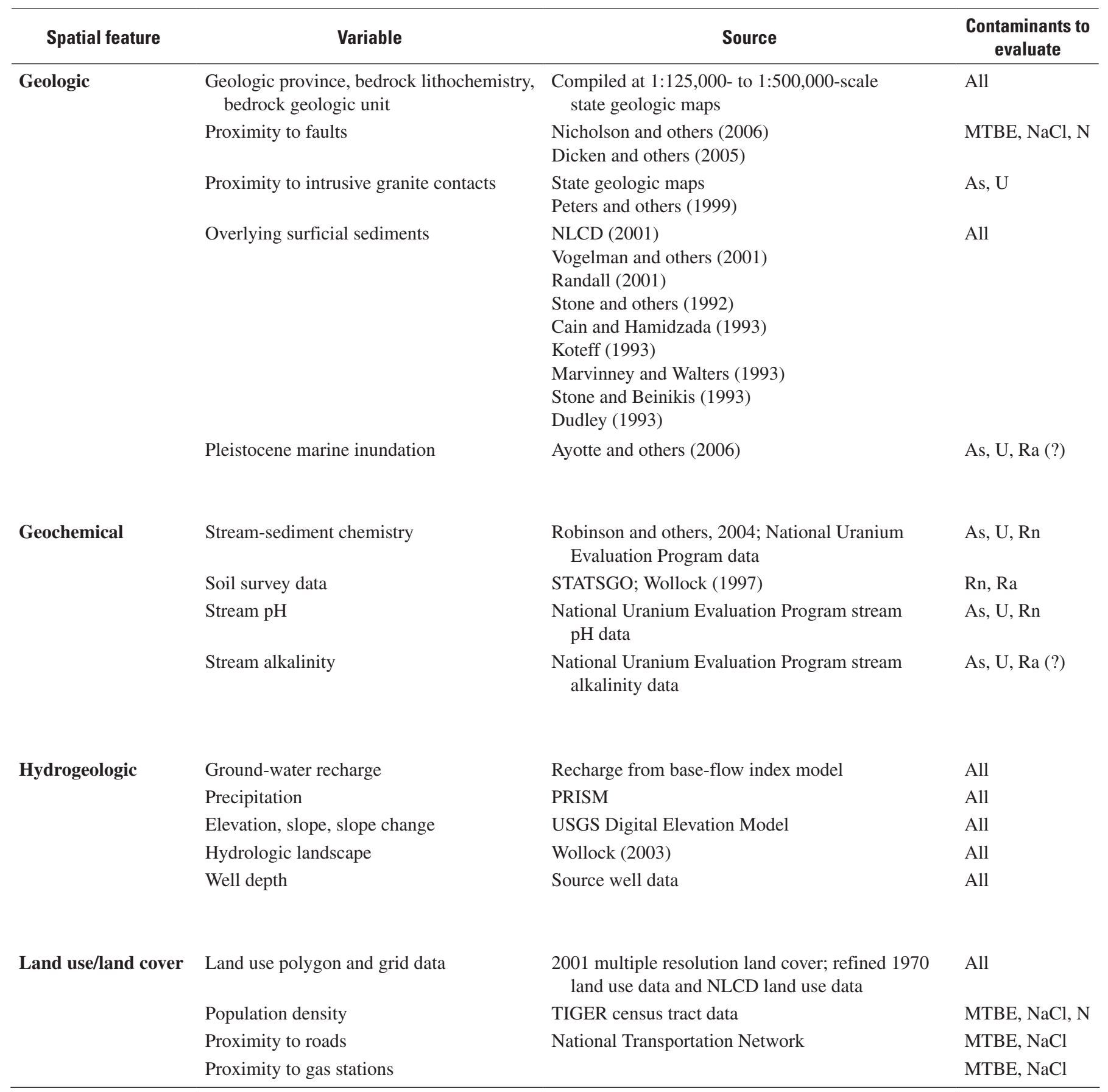


chemistry, and physiochemical conditions such as $\mathrm{pH}$, redox state, and ground-water age. Ground water physiochemical conditions have not been mapped at a regional scale, so measurement of water quality at individual wells are used as an indicator of conditions. The framework, therefore, uses geologic and other landscape features, in part, as a surrogate for the general patterns and regional variation in these physiochemical conditions.

The geologic categorical features are based on information derived from statewide maps of bedrock geology for Connecticut (Rogers, 1985), Maine (Osberg and others, 1985), Massachusetts (Zen and others, 1983), New Hampshire (Lyons and others, 1997), Rhode Island (Hermes and others, 1994), and Vermont (Doll and others, 1961). The geologic features include individual geologic map units and groups of geologic map units that have been generalized into geologic province (regional scale) and lithologic group categories. The province groups were defined by use of lithostratigraphic information and correlation tables accompanying the state bedrock geologic maps (referenced above), and they generally occur as north- to northeast-trending belts that share common features of lithology, age of formation, geologic setting, and tectonic history (Robinson and Kapo, 2003; fig. 1). The lithology group categories generalize the geologic map units according to their lithochemistry that relates to the generalized geochemical and mineralogical composition of the rocks and the signature that they would impart to the ground water flowing within them (Robinson and Kapo, 2003). Because this feature is based on chemical composition and mineralogy, it is useful in the regional analysis of constituents that are sensitive to rock-water interactions (Robinson and others, 2002). The individual geologic map units represent the most local-scale variability related to physiochemical properties of the aquifer and contaminant occurrence and distribution.

Other geologic features that may be used as a surrogate for variation in physiochemical conditions of the aquifer include proximity to geologic structures and contacts and overlying surficial geologic units (table 6). Proximity to faults and lineaments (which may be bedrock fracture zones) is a geologic framework variable that may relate to features such as ground-water recharge rates, dilution, flow rates, and ground-water residence time. Proximity to intrusive granite contacts with associated hydrothermal alteration may be a useful geologic variable because such controls may delineate mineralized areas varying in natural-contaminant source concentrations, as well as physiochemical properties. An example of an overlying surficial geologic variable is information on soil characteristics (STATSGO) including permeability, percentage of organic matter, and texture. Soil characteristics are factors in contaminant occurrence and distribution in other parts of the world (Smedley and Kinniburgh, 2002). Pleistocene marine inundation is another surficial geologic feature that may affect regional ground-water quality. Pleistocene marine inundation can affect chemistry of overlying sediments through residual pore waters with increased salinity and enhanced cation exchange, alteration in clay chemistry, and increased ground-water $\mathrm{pH}$ (Ayotte and others, 2006). These pore waters may recharge underlying crystalline rock aquifers and interact with rock mineralogy and influence ground-water chemistry in the bedrock.

The geochemical features, some of which are listed in table 6 , can be considered as surrogates for variation in natural contaminant sources and influences on geochemical processes in the aquifer. Hydrogeologic features influence hydrologic recharge, flow conditions, and residence time. Land-use and land-cover features are considered surrogates for anthropogenic contaminant sources and potential influences on mobilization of natural contaminants.

Table 7 lists proposed natural and anthropogenic constituents to be examined in regional evaluation of the NECRA. It includes a list of explanatory variables, related measurable characteristics, and related interpretation (effect). For example, nitrogen, a primarily anthropogenic contaminant, is related to land use and particularly to agricultural practices as well as to atmospheric sources through precipitation. 
Table 7. Ground-water contaminants in relation to explanatory variables in regional studies in the New England crystalline rock aquifers.

[As, arsenic; U, uranium; Ca, calcium; Rn, radon; Th, thorium; N, nitrogen; MTBE, methyl tert-butyl ether; Cl, chloride; Na, sodium; salt, sodium, chloride, and trace contaminants

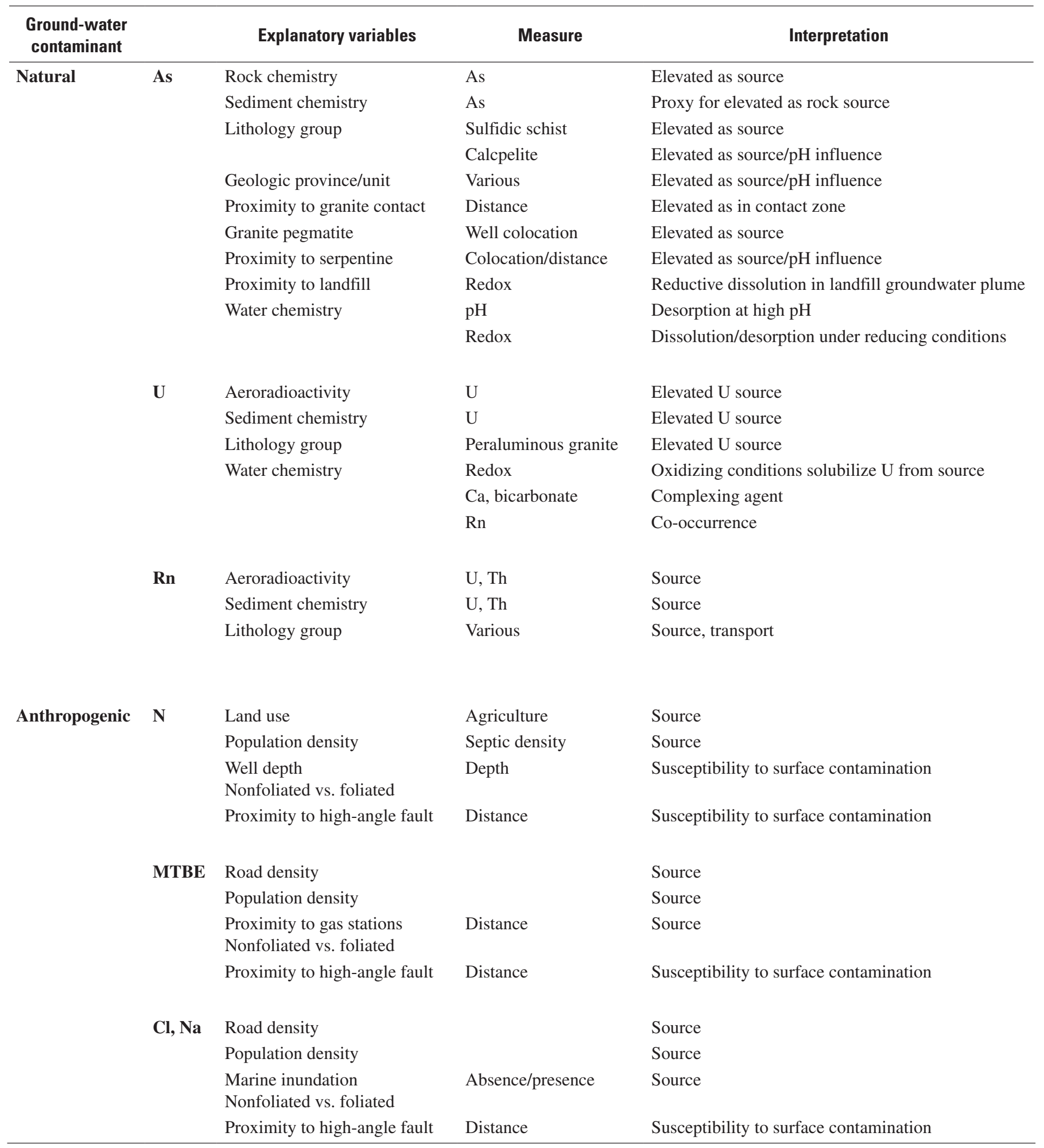




\section{Framework Approach}

The relation between physical and chemical processes in controlling ground-water quality in the crystalline rock aquifers suggests that a linked physical and chemical approach may be useful for the analysis of anthropogenic and natural contaminants. This approach contained herein incorporates the hypothesized most relevant explanatory variables from the hydrostructural domain and lithochemical approaches as well as variables identified from previous investigations of water quality. The framework can be used to characterize the aquifer region into areas of similar hydrologic characteristics and contaminant sources for which water quality can be compared.

The proposed framework approach is diagrammed in a flowchart shown in figure 10. The flowchart is structured under three main factors (source, intrinsic susceptibility, and vulnerability) that likely affect the distribution of contaminants on a regional scale. Under each of the three factors is a set of features (geologic, hydrophysiographic, etc). Within each feature there are set of subcategories, such as bedrock, and a listing of relevant explanatory variables under each subcategory, such as lithologic group. The listing of explanatory variables in this way follows the general approach developed by Warner and Arnold (2006) and groups the variables under source, susceptibility, and vulnerability factors. Although some variables are listed as a source or susceptibility factor, all variables fall under the vulnerability factor.

The result of the application of the framework approach will be a vulnerability assessment to the contaminant of interest and an indication of potential factors that affect the occurrence, distribution, and fate of contaminants. The main benefits to the use of the framework approach are that it lists relevant explanatory variables and it specifies a systematic, structured approach to test potential relations between variables and regional water quality.

An important criterion in the framework approach is whether the contaminant (or constituent) is anthropogenic or naturally derived (source factor). However, many of the same explanatory variables are used in evaluating vulnerability because of the interdependence between physical and chemical processes. For example, an anthropogenic contaminant like MTBE may correlate to land-use practices, but it is also possible that land use can affect general chemical conditions that in turn affect mobilization of certain metals. Thus, land use is listed as a source factor but also listed as a vulnerability factor (fig. 9).

Variables listed under intrinsic susceptibility factors incorporate generalized physical characteristics of the aquifer system that influence ground-water chemistry and flow. For example, the variable ground-water recharge, a hydrophysiographic feature listed under the hydrologic category, is an intrinsic susceptibility factor that affects dilution and water chemistry. Some variables are both a source and susceptibility factor and are connected, such as bedrock geology. Waterchemistry explanatory variables incorporate the effect of source, intrinsic susceptibility, and vulnerability factors and are listed at the bottom of the framework. Variables related to well characteristics of individual wells and water samples are listed near the end of the vulnerability assessment. Well characteristics provide information on the location and source of the water sample and may provide insight into factors such as degree of mixing of the water sample and vulnerability of the sample to contamination.

All data on explanatory variables are readily available for regional spatial analysis. For example, regional fault information is available at a 1:250,000 scale from USGS sources (Nicholson and others, 2006; Dicken and others, 2005). Soil cover is available from STATSGO (state soil surveys from NRCS). Soil cover will include features such as surface-water bodies and wetlands. Although surficial geologic maps may provide more detail than soil surveys on the characteristics of overburden sediments, detailed surficial geologic maps are unavailable on a regional scale.

Several variables are proxies for other important variables. Regional structural and fracture trends are unavailable; therefore, proximity to geologic faults, geologic province, lithology group, and geologic map unit variables are used as proxies for variation in structural features. For example, an important variable in the study of bedrock yield and recharge is the presence of steeply sloping (near vertical) foliations and partings. If these characteristics are present, they can transmit vertical flow from overlying sources and thus have the potential for increased yield (Lyford and Walsh, 2004; Manda and others, 2007). Therefore, although specific fracture information is unavailable locally, the presence or absence of foliated rock can be used to identify areas with the potential for vertical fractures.

Natural and anthropogenic constituent concentrations can be evaluated with variables shown in figure 10 by means of a variety of statistical methods such as univariate analysis or multivariate analysis (correlations, regression, principal component analysis, logistic regression, cluster analysis, and multivariate analysis of variance). Additional information on these statistical methods is available in Alley (1993) and in a more recent article by Woocay and Walton (2008).

The likelihood of variables affecting regional water quality can be further assessed by use of geochemical models. Forward geochemical models can be used to determine the water chemistry (output) in the rock aquifer if the recharge water chemistry (input) and the lithochemistry of the rock are known (Parkhurst and others, 1999). The output results of the forward model can be compared to the actual water quality of the aquifer to identify the effect of various input water chemistry on the overall water quality of the aquifer. Inverse geochemical models can be used to identify the lithochemical reactions controlling the rock water chemistry (Plummer and others, 1994) and, therefore, identify important mineral reactions. A case example of geochemical modeling to identify flowpath reactions in the NECRA of the Mirror Lake area is presented in Harte and Winter (1996). 
Factors

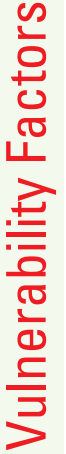

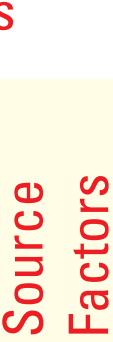

\section{Ground-Water Contaminant}

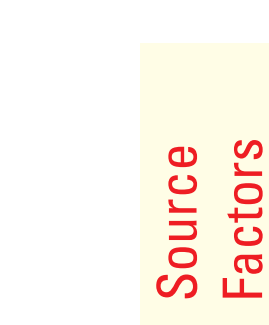

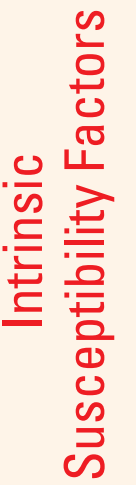

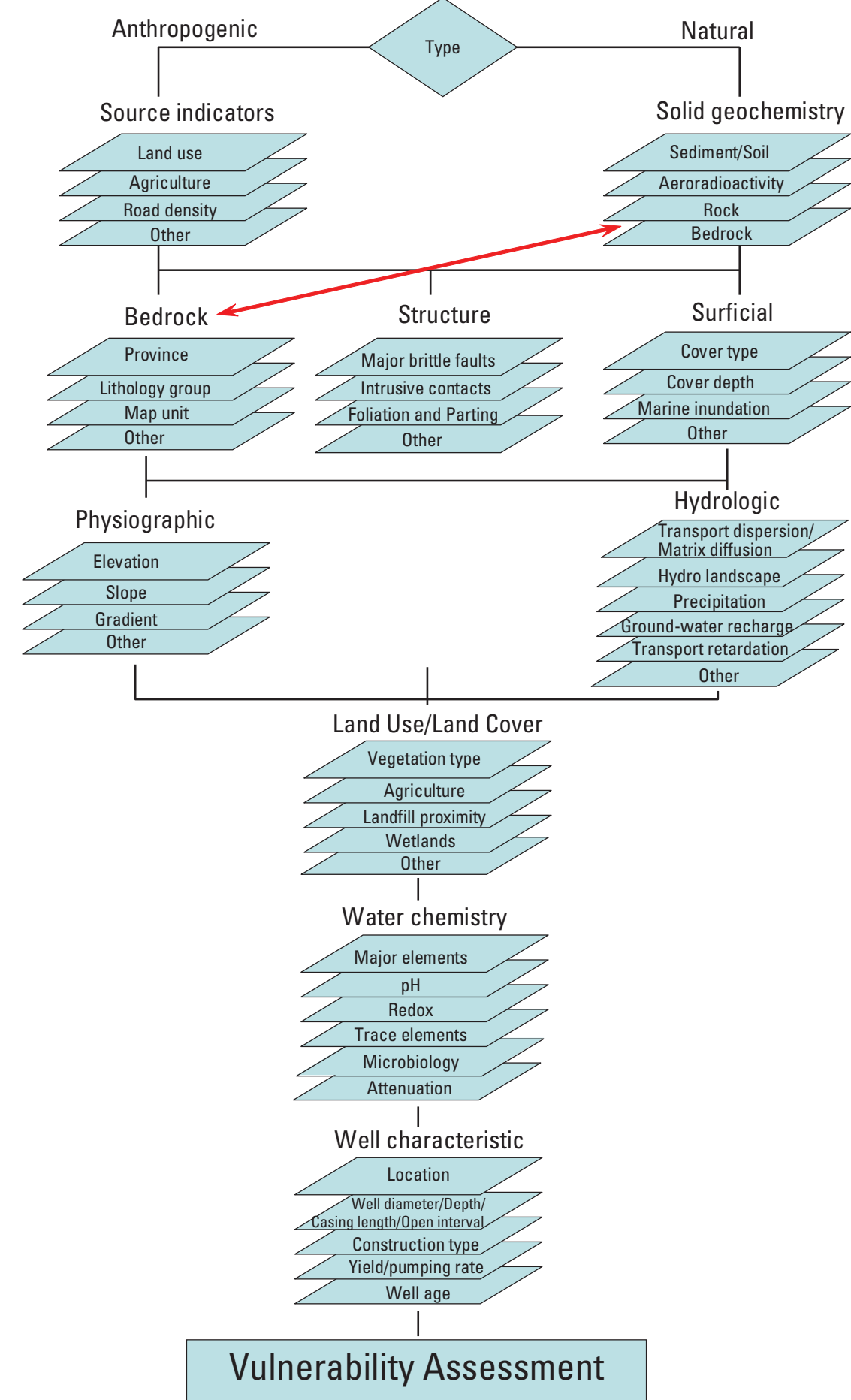

Features

๑

응

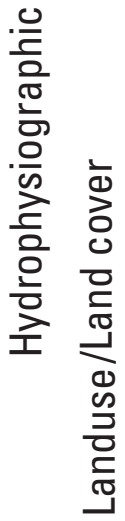

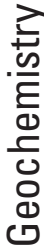

흠

Figure 10. Preliminary framework approach for the evaluation of regional ground-water quality in the New England crystalline rock aquifers. 


\section{References}

Aller, L., Bennett T., Lehr, J.H., Petty, R.J., and Hackett, G., 1987, DRASTIC: A standardized system for evaluating ground water pollution potential using hydrogeologic settings: U.S. Environmental Protection Agency, NWWA/EPA series, EPA-600/2-97-035, variously paginated.

Alley, W.M., ed., 1993, Regional ground water quality: New York, Van Nostrand Reinhold, 634 p.

Ayers, M.A., Kennen, J.G., and Stackelberg, P.E., 2000, Water quality in the Long Island-New Jersey Coastal Drainages, New York and New Jersey, 1996-98: U.S. Geological Survey Circular 1201, 40 p.

Ayotte, J.D., Argue, D.M., and McGarry, F.J., 2005, Methyl tert-butyl ether occurrence and related factors in public and private wells in southeast New Hampshire: Environmental Science and Technology, v. 39, no. 1, p. 9-16.

Ayotte, J.D., Argue, D.M., McGarry, F.J., Degnan, J.R., Hayes, Laura, Flanagan, S.M., and Helsel, D.R., 2008, Methyl tert-butyl ether (MTBE) in public and private wells in New Hampshire: Occurrence, factors, and possible implications: Environmental Science and Technology, v. 42, no. 3, p. $677-684$.

Ayotte, J.D., Flanagan, S.M., and Morrow, W.S., 2007, Occurrence of uranium and ${ }^{222}$ radon in glacial and bedrock aquifers in the northern United States, 1993-2003: U.S. Geological Survey Scientific Investigations Report 2007-5037, 84 p.

Ayotte, J.D., Montgomery, D.L., Flanagan, S.M., and Robinson, K.W., 2003, Arsenic in groundwater in eastern New England: Occurrence, controls, and human health implications: Environmental Science and Technology, v. 37 , no. 10 , p. 2075-2083.

Ayotte, J.D., Mrazik, B.R., Argue, D.M., and McGarry, F.J., 2004, Occurrence of methyl tert-butyl ether (MTBE) in public and private wells, Rockingham County, New Hampshire: U.S. Geological Survey Fact Sheet 2004-3119, 4 p.

Ayotte, J.D., Nielsen, M.G., Robinson, G.R., Jr., and Moore, R.B., 1999, Relation of arsenic, iron, and manganese in ground water to aquifer type, bedrock lithogeochemistry, and land use in the New England Coastal Basins: U.S. Geological Survey Water-Resources Investigations Report 99-4162, $61 \mathrm{p}$.
Ayotte, J.D., Nolan, B.T., Nuckols, J.R., Cantor, K.P., Robinson, G.R., Jr., Baris, Dalsu, Hayes, Laura, Karagas, Margaret, Bress, William, Silverman, D.T., and Lubin, J.H., 2006, Modeling the probability of arsenic in groundwater in New England as a tool for exposure assessment: Environmental Science and Technology Journal, v. 40, no. 11, p. 3578-3585.

Banks, David, Frengstad, Bjorn, Midtgard, A.K., Krog, J.R., and Strand, Terje, 1998, The chemistry of Norwegian groundwaters: I. The distribution of radon, major and minor elements in 1604 crystalline bedrock groundwaters: The Science of Total Environment, v. 222, p. 71-91.

Banks, David, and Robins, Nick, 2002, An introduction to groundwater in crystalline bedrock: Geological Survey of Norway, N-7491, Trondheim, Norway, p. 68.

Cain, J.A., and Hamidzada, N.A., 1993, Rhode Island sand and gravel resources: New England Governor's Conference, Inc., Boston, Mass., 15 p., 1 pl., 1:250,000 scale.

Cheney, J.T., and Hepburn, J.C. (eds.), 1993, Field trip guidebook for the northeastern United States: 1993 Boston GSA, v. 1 and 2: Geological Society of America Annual Meeting and 85th Annual New England Intercollegiate Geological Conference Meeting, Boston, Mass.

Coakley, M.F., Keirstead, Chandlee, Brown, R.O., and Kiah, R.G., 2000, Water resources data New Hampshire and Vermont water year 2000: U.S. Geological Survey WaterData Report NH-VT-00-1, 192 p.

Coakley, M.F., Kiah, R.G., Ward, S.L., and Hilgendorf, G.S., 1999, Water resources data New Hampshire and Vermont water year 1999: U.S. Geological Survey Water-Data Report NH-VT-99-1, 184 p.

Cook, P.G., Love, A.J., Robinson, N.I., and Simmons, C.T., 2005, Groundwater ages in fractured rock aquifers: Journal of Hydrology, v. 308, p. 284-301.

Denny, C.S., 1982, Geomorphology of New England: U.S. Geological Survey Professional Paper 1208, 18 p., $1 \mathrm{pl}$.

Dicken, C.L., Nicholson, S.W., Horton, J.D., Kinney, S.A., Gunther, Gregory, Foose, M.P., and Mueller, Julia, A.L., 2005, Preliminary integrated geologic map databases for the United States-Delaware, Maryland, New York, Pennsylvania, and Virginia: U.S. Geological Survey OpenFile Report 2005-1325, variously paginated [accessed online only].

Doll, C.G., Cady, W.M., Thompson, J.B., Jr., and Billings, M.P., eds. and compilers, 1961, Centennial geology map of Vermont: Montpelier, Vt., U.S. Geological Survey, scale 1:250,000, 1 sheet. 
Dudley, John, 1993, Sand and gravel resource map of Vermont: New England Governor's Conference, Inc., Boston, Mass., 3 pls., scale 1:250,000.

Einarson, M.D., and Mackay, D.M., 2001, Predicting the impacts of ground water contamination: Environmental Science and Technology, v. 35, no. 3, p. 67A-73A.

Fenneman, N.M., 1938, Physiography of eastern United States: New York and London, McGraw-Hill Book Company, $714 \mathrm{p}$.

Flanagan, S.M., Nielsen, M.G., Robinson, K.W., and Coles, J.F., 1999, Water-quality assessment of the New England Coastal Basins in Maine, Massachusetts, New Hampshire, and Rhode Island: Environmental settings and implications for water quality and aquatic biota: U.S. Geological Survey Water-Resources Investigations Report 98-4249, 64 p.

Focazio, M.J., Reilly, T.E., Rupert, M.G., and Helsel, D.R., 2002, Assessing ground-water vulnerability to contamination: Providing scientifically defensible information for decision makers: U.S. Geological Survey Circular 1224, $33 \mathrm{p}$.

Garabedian, S.P., Coles, J.F., Grady, S.J., Trench, E.C.T., and Zimmerman, M.J., 1998, Water-quality assessment of the Connecticut, Housatonic, and Thames River Basins, 1991-95: U.S. Geological Survey Circular 1155, 32 p.

Gilliom, R.J., Barbash, J.E., Crawford, C.G., Hamilton, P.A., Martin, J.D., Nakagaki, Naomi, Nowell, L.H., Scott, J.C., Stackelberg, P.E., Thelin, G.P., and Wolock, D.M., 2007, Pesticides in the Nation's streams and ground water, 1992-2001: U.S. Geological Survey Circular 1291, 172 p.

Grady, S.J., 1997, Volatile organic compounds in ground water in the Connecticut, Housatonic, and Thames River Basins, 1993-1995: U.S. Geological Survey Fact Sheet FS-029-97, $6 \mathrm{p}$.

Hansen, B.P., and Simcox, A.C., 1994, Yields of bedrock wells in Massachusetts: U.S. Geological Survey Water-Resources Investigations Report 93-4115, 43 p.

Harte, P.T., 1992, Regional ground-water flow in crystalline bedrock and interaction with glacial drift in the New England Uplands [Masters thesis]: University of New Hampshire, Durham, N.H., 147 p.

Harte, P.T., and Winter, T.C., 1996, Factors affecting recharge to crystalline rock in the Mirror Lake area, Grafton County, New Hampshire, in Morganwalp, D.W., and Aronson, D.A., eds., U.S. Geological Survey Toxic Substances Hydrology Program-Proceedings of the technical meeting, Colorado Springs, Colo., September 20-24, 1993: U.S. Geological Survey Water-Resources Investigations Report 94-4015, v. 1, p. 141-150.
Hermes, O.D., Gromet, L.P., and Murray, D.P., 1994, Bedrock geologic map of Rhode Island: Kingston, R.I., Office of the Rhode Island State Geologist, Rhode Island Map Series no. 1, 1 map sheet, scale 1:100,000.

Homer, C., Huang, C., Yang, L., Wylie, B., and Coan, M., 2004, Development of a 2001 national land cover database for the United States: Photogrammetric Engineering and Remote Sensing, v. 70, no. 7, p. 829-840, at www.mrlc.gov/ publications, accessed November 21, 2008, at http://water. usgs.gov/GIS/metadata/usgswrd/XML/nlcd01_2.xml

Hutson, S.S., Barber, N.L., Kenny, J.F., Linsey, K.S., Lumia, D.S., and Maupin, M.A., 2004, Estimated use of water in the United States in 2000: Reston, Va., U.S. Geological Survey Circular 1268, 46 p.

Katz, Joshua, 2007, Road salt in bedrock aquifers-Is there a problem? in Geological Society of America Abstract with Programs, Northeastern section annual meeting: Durham, N.H., March 2007, v. 39, no. 1, p. 58.

Kim, Jonathan, Springston, George, Gale, Marjorie, Dunn, Richard, and Becker, Lawrence, 2006, Geologic Framework for evaluating ground water resources in Worcester Mountains, central Vermont: Abstract in Northeast Section Geological Society of America Meeting 2006, Durham, N.H., 1 p.

Kontis, A.L., Randall, A.D., and Mazzaferro, D.L., 2004, Regional hydrology and simulation of flow of stratifieddrift aquifers in the glaciated northeastern United States: U.S. Geological Survey Professional Paper 1415-C, 156 p.

Koteff, Carl, 1993, Sand and gravel resources of New Hampshire: New England Governors' Conference, Inc., Boston, Mass., 3 pls., scale 1:250,000.

Lapham, W.W., 1990, A plan for the study of the hydrogeology of bedrock of New England: U.S. Geological Survey OpenFile Report 90-374, 16 p.

Lapham, W.W., Hamilton, P.A., and Myers, D.N., 2005, National Water-Quality Assessment Program-Cycle IIregional assessments of aquifers: U.S. Geological Survey Fact Sheet 2005-3013, 4 p.

Lindsey, B.D., Falls, W.F., Ferrari, M.J., Zimmerman, T.M., Harned, D.A., Sadorf, E.M., and Chapman, M.J., 2006, Factors affecting occurrence and distribution of selected contaminants in ground water from selected areas in the Piedmont Aquifer System, eastern United States, 1993-2003: U.S. Geological Survey Scientific Investigations Report 2006-5104, 72 p.

LipFert, Gail, Reeve, A.S., Sidle, W.C., and Marvinney, Robert, 2006, Geochemical patterns of arsenic-enriched ground water in fractured, crystalline bedrock, Northport, Maine: Applied Geochemistry, v. 21, issue 3, p. 528-545. 
Lyford, F.P., Carlson, C.S., and Hansen, B.P., 2003, Delineation of water sources for public-supply wells in three fractured-bedrock aquifer systems in Massachusetts: U.S. Geological Survey Water-Resources Investigations Report 02-4290, $113 \mathrm{p}$.

Lyford, F.P., and Walsh, G.J., 2004, A conceptual framework for predicting sustainable well yields in crystalline rock aquifers, examples from Massachusetts: Geological Society of America, Abstracts with Programs, v. 36, no. 2, p. 92-93.

Lyons, J.B., Bothner, W.A., Moench, R.H., and Thompson, J.B., Jr., 1997, Bedrock geologic map of New Hampshire: Reston, Va., U.S. Geological Survey Special Map, 2 map sheets, scale 1:250,000.

Mabee, S.B., 1992, Lineaments: Their value in assessing groundwater availability and quality in bedrock aquifers of glaciated metamorphic terrains-A case study: Amherst, Mass., University of Massachusetts, Ph.D. dissertation, $567 \mathrm{p}$.

Mabee, S.B., 1999, Factors influencing well productivity in glaciated metamorphic rocks: Ground Water, v. 37, no. 1, p. $88-97$.

Mabee, S.B., and Kopera, J.P., 2005, Fracture characterization maps: A new type of geologic map for hydrogeologic applications in Geological Society of America Abstract with Programs, Annual meeting, v. 37, no. 7, p. 145.

Manda, A.K., Mabee, S.B., and Boutt, D.F., 2006, Characterizing fractured crystalline bedrock aquifers using hydrostructural domains in the Nashoba Terrane, Eastern Massachusetts: Geological Society of America Annual Meeting, Philadelphia, Pa., October 22-25, 2006, 1 p.

Manda, A.K., Mabee, S.B., and Hubbs, S.A., 2005, Field mapping and fracture characterization techniques predict groundwater preferential flow paths in fractured bedrock aquifers, Nashoba Terrane, Mass.: American Geophysical Union Fall Meeting, San Francisco, Calif., 1 p.

Manda, A.K., Mabee, S.B., and Wise, D.U., 2007, Influence of rock fabric on fracture attribute distribution and implications for groundwater flow in the Nashoba Terrane, eastern Massachusetts: Journal of Structural Geology, v. 30, no. 4, p. 464-477.

Marvinney, R.G., and Thompson, W.B., 2000, A geologic history of Maine, King, V.T. (ed.) in Mineralogy of Maine, v. 2, Mining history, gems, and geology: Maine Geological Survey, p. 1-8.

Marvinney, R.G., and Walters, D.H., 1993, Sand and gravel resources of Maine: New England Governors' Conference, Inc., Boston, Mass., 2 pls., scale 1:250,000.
Maupin, M.A., and Barber, N.L., 2005, Estimated withdrawals from principal aquifers in the United States, 2000: U.S. Geological Survey Circular Report 1279, 42 p.

Mayo, Matthew, Tedder, Newton, Billings, Jay, and Frisch, Joel, 2007, Arsenic in ground water and surface water at landfills in central Massachusetts, Geological Society of America Abstracts with Programs, v. 39, no. 1, p. 71.

Montgomery, D.L., Robinson, G.R., Jr., Ayotte, J.D., Flanagan, S.M., and Robinson, K.W., 2002, Digital data set of generalized lithogeochemical characteristics of nearsurface bedrock in the New England Coastal Basins: U.S. Geological Survey Fact Sheet FS-003-02, 4 p.

Moore, R.B., 2004, Quality of water in the fractured bedrock aquifer of New Hampshire: U.S. Geological Survey Scientific Investigations Report 2004-5093, 30 p.

Moore, R.B., Schwarz, G.E., Clark, S.F., Jr., Walsh, G.J., and Degnan, J.R., 2002a, Factors related to well yield in the fractured-bedrock aquifer of New Hampshire: U.S. Geological Survey Professional Paper 1660, 51 p.

Moore, R.B., Schwarz, G.E., Clark, S.F., Jr., Walsh, G.J., Degnan, J.R., and Mack, T.J., 2001, Relating well yields to site characteristics in fractured bedrock of New Hampshire, in Geological Society of America, annual meeting and exposition, Boston, Mass., November 5-8, 2001, Abstracts with Programs: Boston, Mass., Geological Society of America, online at http://gsa.confex.com [ABSTRACT]

Moore, R.B., Schwarz, G.E., Clark, S.F., Jr., Walsh, G.J., Degnan, J.R., and Mack, T.J., 2002b, Well-yield probabilities related to site and well characteristics in the fracturedbedrock aquifer of New Hampshire, in Fractured-Rock Aquifers 2002 Conference, Denver, Colo., March 13-15, 2002, Proceedings: National Ground Water Association, U.S. Environmental Protection Agency, U.S. Geological Survey, p. 37.

Mossmark, Frederik, Hultberg, Hans, and Ericsson, L.O., 2007, Effects of groundwater extraction from crystalline hard rock on water chemistry in an acid forested catchment at Gardsjon, Sweden: Applied Geochemistry, v. 22, no. 6, p. $1157-1166$.

Navulur, K.C.S., and Engel, B.A., 1998, Groundwater vulnerability assessment to non-point source nitrate pollution on a regional scale using GIS, Trans. ASAE 41 (1998), pp. 1671-1678.

Nelms, D.L., Harlow, G.E., Jr., Plummer, L.N., and Busenberg, Eurybiades, 2003, Aquifer susceptibility in Virginia, 1998-2000: U.S. Geological Survey WaterResources Investigations Report 03-4278, 58 p. 
Nicholson, S.W., Dicken, C.L., Horton, J.D., Foose, M.P., Mueller, J.A.L., and Hon, Rudi, 2006, Preliminary integrated geologic map databases for the United States-Connecticut, Maine, Massachusetts, New Hampshire, New Jersey, Rhode Island and Vermont: U.S. Geological Survey Open-File Report 2006-1272, variously paginated, online only at http://pubs.usgs.gov/of/2006/1272/

Nolan, B.T., and Hitt, K.J., 2006, Vulnerability of shallow groundwater and drinking-water wells to nitrate in the United States: Environmental Science and Technology Journal, v. 40, no. 24, p. 7834-7840.

Oremland, R.S., and Stolz, J.F., 2003, The ecology of arsenic: Science 300, p. 939-944.

Osberg, P.H., Hussey, A.M., II, and Boone, G.M., 1985, Bedrock geologic map of Maine: Augusta, Maine, Maine Geological Survey, 1 map sheet, scale 1:500,000.

Parkhurst, D.L., and Appelo, C.A.J., 1999, User's guide to PHREEQC (Version 2) - A computer program for speciation, batch-reaction, one-dimensional transport, and inverse geochemical calculations: U.S. Geological Survey WaterResources Investigations Report 99-4259, 310 p.

Peters, S.C., Blum, J.D., Klane, Bjoern, and Karagas, M.R., 1999, Arsenic occurrence in New Hampshire drinking water: Environmental Science and Technology, v. 33, no. 9, p. $1328-1333$.

Plummer, L.N., Prestemon, E.C., and Parkhurst, D.L., 1994, An interactive code (NETPATH) for modeling NET geochemical reactions along a flow PATH, version 2.0: U.S. Geological Survey Water-Resources Investigations Report 94-4169, $130 \mathrm{p}$.

Randall, A.D., 2001, Hydrogeologic framework of stratifieddrift aquifers in the glaciated northeastern United States: U.S. Geological Survey Professional Paper 1415-B, 179 p.

Robinson, G.R., Jr., 1997, Portraying chemical properties of bedrock for water quality and ecosystem analysis: An approach for the New England Region: U.S. Geological Survey Open-File Report 97-154, 17 p.

Robinson, G.R., Jr., and Ayotte, J.D., 2006, The influence of geology and land use on arsenic in stream sediments and ground waters in New England, U.S.A.: Applied Geochemistry, v. 21, issue 9, p. 1482-1497.

Robinson, G.R., Jr., Ayotte, J.D., Montgomery, D.L., and DeSimone, L.A., 2002, Lithogeochemical character of near-surface bedrock in the New England Coastal Basins: U.S. Geological Survey Open-File Report 02-007, digital data set.
Robinson, G.R., Jr., and Kapo, K.E., 2003, Generalized lithology and lithogeochemical character of near-surface bedrock in the New England region: U.S. Geological Survey OpenFile Report 03-225, online only at http://pubs.usgs.gov/ of/2003/of03-225/

Robinson, G.R., Jr., Kapo, K.E., and Grossman, J.N., 2004, Chemistry of stream sediments and surface waters in New England: U.S. Geological Survey Open-File Report 04-1026, 18 p., online only at http://pubs.usgs.gov/ of/2004/1026/pdf/OFR2004-1026_text.pdf

Robinson, G.R., Jr., Peper, J.D., Steeves, P.A., and DeSimone, L.A., 1999, Lithogeochemical character of near-surface bedrock in the Connecticut, Housatonic, and Thames River Basins: U.S. Geological Survey Water-Resources Investigations Report 99-4000, digital data set.

Robinson, K.W., Flanagan, S.M., Ayotte, J.D., Campo, K.W., Chalmers, Ann, Coles, J.F., and Cuffney, T.F., 2004, Water quality in the New England Coastal Basins, Maine, New Hampshire, Massachusetts, and Rhode Island, 1999-2001: U.S. Geological Survey Circular 1226, p. 38.

Rogers, John (compiler), 1985, Bedrock geological map of Connecticut: Connecticut Geologic and Natural History Survey, Natural Resource Atlas Map Series, 2 map sheets, scale 1:125,000.

Rogers, R.J., 1989, Geochemical comparison of ground water in areas of New England, New York, and Pennsylvania: Ground Water, v. 27, no. 5, p. 690-712.

Scott, J.C., 1990, Computerized stratified random siteselection approaches for design of ground-water quality sampling network: U.S. Geological Survey WaterResources Investigations Report 90-4101, 109 p.

Seaton, W.J., and Burbey, T.J., 2005, Influence of ancient thrust faults on the hydrogeology of the Blue Ridge Province: Ground Water, v. 43, no. 3, p. 301-313.

Shapiro, A.M., 2003, Characterizing fractured rockHydrogeologic conceptual models of ground-water flow and the influence of problem scale: U.S. Environmental Protection Agency, 2003, online at epa.gov/tio/tsp/download/2003_meeting_fall/shapiro_abstract.pdf

Shedlock, R.J., Hamilton, P.A., Denver, J.M., and Phillips, P.J., 1993, Multiscale approach to regional ground-water quality assessment of the Delmarva Peninsula in Regional Ground-Water Quality, Alley, W.M., ed.: Van Nostrand Reinhold publisher, N.Y., p. 563-587.

Sinnott, Allen, 1982, Summary appraisals of the Nation's ground-water resources-New England region: U.S. Geological Survey Professional Paper 813-T, 23 p. 
Smedley, P.L., and Kinniburgh, D.G., 2002, A review of the source, behavior and distribution of arsenic in natural waters: Applied Geochemistry, v. 17, no. 5, p. 517-568.

State of Maine, 1998, The presence of MTBE and other gasoline compounds in Maine's drinking water: State of Maine, Augusta, Maine, $15 \mathrm{p}$.

Stollenwerk, K.G., 2003, Geochemical processes controlling transport of arsenic in groundwater: A review of adsorption, in Welch, A.H., and Stollenwerk, K.G., eds., Arsenic in Ground Water: Geochemistry and Occurrence: Boston, Kluwer Academic Publishers, p. 67-100.

Stollenwerk, K.G., and Colman, J.A., 2004, Natural remediation of arsenic contaminated ground water associated with landfill leachate: U.S. Geological Survey Fact Sheet 2004-3057, 4 p.

Stone, B.D., and Beinikis, A.I., 1993, Sand and gravel resources of Massachusetts: New England Governors' Conference, Inc., Boston, Mass., 3 pls., scale 1:250,000.

Stone, J.R., Schafer, J.P., London, E.H., and Thompson, W.B., 1992, Surficial materials boundaries from 1:24,000 scale compilation sheets prepared for the Surficial Materials Map of Connecticut: U.S. Geological Survey special map, 2 sheets, scale 1:125,000.

Sullivan, Colleen, Bright, Kevin, Kim, Jonathan, and Ryan, P.C., 2007, Potential ultramafic-derived arsenic contamination in bedrock water wells in north-central Vermont: Geological Society of America Abstracts with Programs, v. 39 , no. 1 , p. 71 .

Taylor, Charlotte, Levin, Emily, Martini, Anna, and Mabee, Steve, 2001, Hydrogeochemistry of groundwater flow through bedrock fractures: The Metrowest Water Supply Tunnel, Mass.: Geological Society of America Annual Meeting, Boston, Mass., November 5, 2001, 1 p.

Tiedeman, C.R., Goode, D.J., and Hsieh, P.A., 1998, Characterizing a ground water basin in a New England mountain and valley terrain: Ground Water, v. 36, no. 4, p. 611-620.

U.S. Department of Commerce, 1977, Climate of New Hampshire: National Oceanic and Atmospheric Administration Climatography of the United States, no. 60, 15 p.

U.S. Department of Commerce, 1982a, Climate of Maine: National Oceanic and Atmospheric Administration Climatography of the United States, no. 60, $15 \mathrm{p}$.

U.S. Department of Commerce, 1982b, Climate of Massachusetts: National Oceanic and Atmospheric Administration Climatography of the United States, no. 60, 17 p.

U.S. Department of Commerce, 1982c, Climate of Rhode Island: National Oceanic and Atmospheric Administration Climatography of the United States, no. 60, 17 p.
U.S. Environmental Protection Agency, 2006, 2006 Edition of the Drinking Water Standards and Health Advisory: EPA 822-R-06-013, variously paginated.

U.S. Geological Survey, 1985, National Water Summary, 1984-Hydrologic events, selected water-quality trends, and ground-water resources: U.S. Geological Survey Water-Supply Paper 2275, $467 \mathrm{p}$.

U.S. Geological Survey, 2003, Principal aquifers: National Atlas of the United States of America, map scale 1:5,000,000.

U.S. Geological Survey, 2006, National Land Cover Dataset 2001, digital data accessed January 16, 2007, from http://www.mrlc.gov

Utsunomiya, Satoshi, Peters, S.C., Blum, J.D., and Ewing, R.C., 2003, Nanoscale mineralogy of arsenic in a region of New Hampshire with elevated As concentrations in groundwater: American Mineralogist, v. 88, p. 1844-1852.

Veeger, A.I., and Ruderman, N.C., 1998, Hydrogeologic controls on ${ }^{222}$ radon in a buried valley-fractured bedrock aquifer system: Ground Water, v. 36, no. 4, p. 596-604.

Vermont Department of Environmental Conservation, 2004, State of Vermont 2004 Water Quality Report (305B Report), Part Seven, Groundwater Monitoring, p. 60-72.

Wall, G.R., Riva-Murray, Karen, and Phillips, P.J., 1998, Water quality in the Hudson River Basin, 1992-95: U.S. Geological Survey Circular 1165, 32 p.

Warner, K.L., and Arnold, T.L., 2006, Framework for regional synthesis of water-quality data for the glacial aquifer system in the United States: U.S. Geological Survey Scientific Investigations Report 2005-5223, 4 p.

Welch, A.H., Westjohn, D.B., Helsel, D.R., and Wanty, R.B., 2000, Arsenic in ground water of the United Statesoccurrence and geochemistry: Ground Water, v. 38, no. 4, p. 589-604.

Wolock, D.M., 1997, STATSGO soil characteristics for the conterminous United States: U.S. Geological Survey OpenFile Report 1997-656, online only at http://water.usgs.gov/ GIS/metadata/usgswrd/XML/ussoils.xml

Wolock, D.M., 2003, Hydrologic landscape regions of the United States: U.S. Geological Survey Open-File Report 2003-145, online only at http://water.usgs.gov/GIS/ metadata/usgswrd/XML/hlrus.xml

Wolock, D.M., Winter, T.C., and McMahon, G., 2004, Delineation and evaluation of hydrologic-landscape regions in the United States using geographic information system tools and multivariate statistical analyses: Environmental Management, v. 34, p. 71-78. 
Woocay, Arturo, and Walton, John, 2008, Multivariate analysis of water chemistry - surface and ground water interactions; Ground Water, v. 46, no. 3, p. 437-449.

Wood, W.W., Kraemer, T.F., and Shapiro, Allen, 2004, Radon $\left({ }^{222} \mathrm{Rn}\right)$ in ground water of fractured rocks - a diffusion/ion exchange model: Ground Water, v. 42, no. 4, p. 552-567.

Vesterbacka, P., 2005, 238U-series radionuclides in Finnish groundwater-based drinking water and effective doses: Helsinki, Radiation and Nuclear Safety Authority (STUK), University of Helsinki, Department of Chemistry, Laboratory of Radiochemistry STUK-A213, 94 p.

Vesterbacka, P., Makelaninen, I., and Arvela, H., 2005, Natural radioactivity in drinking water in private wells in Finland: Radiation Prevention Dosimetry, v. 113, no. 2, p. 223-232.

Vogelmann, J.E., Howard, S.M., Yang, L., Larson, C.R., Bruce, B.K., and van Driel, N., 2001, Completion of the 1990s National Land Cover Data Set for the conterminous United States from Landsat Thematic Mapper Data and Ancillary Data sources: Photogrammetric Engineering and Remote Sensing, v. 67, no. 6, p. 650-662.
Yang, Qiang, Jung, H.B., Culbertson, Charles, Marvinnney, Robert, Loiselle, Marc, Locke, Daniel, Cheek, Heidi, Thibodeau, Hilary, Hess, C.T., and Zheng, Yan, 2006, Geochemical characteristics of groundwater from domestic wells in greater Augusta area, Maine, U.S.A., in Geological Society of America Abstract with Programs, Annual meeting, Philadelphia, Pa., October 2006, v. 38, no. 7, p. 422.

Zapecza, O.S., Kauffman, L.J., Rice, D.E., and DePaul, V.T., 2004, Effects of geology and urban sprawl on the water resources of the New York-New Jersey Highlands Region in Geological Society of America Abstract with Programs, Northeastern section meeting, v. 36, no. 2, p. 93.

Zen, E-an, Goldsmith, Richard, Ratcliffe, N.M., Robinson, Peter, and Stanley, R.S., 1983, Bedrock geologic map of Massachusetts: U.S. Geological Survey, Monograph Series, 3 map sheets, scale 1:250,000.

Zogorski, J.S., Carter, J.M., Ivahnenko, Tamara, Lapham, W.W., Moran, M.J., Rowe, B.L., Squillace, P.J., and Toccalino, P.L., 2006, Volatile organic compounds in the Nation's ground water and drinking-water supply wells: U.S. Geological Survey Circular 1292, 101 p. 
Table 4. Summary of factors affecting regional water quality in crystalline rocks of the New England area.

[N/A, not applicable; mg/kg, milligrams per kilograms; As, arsenic; U, uranium; ppm, parts per million; MTBE, methyl tert-butyl ether; VOCs, volatile organic

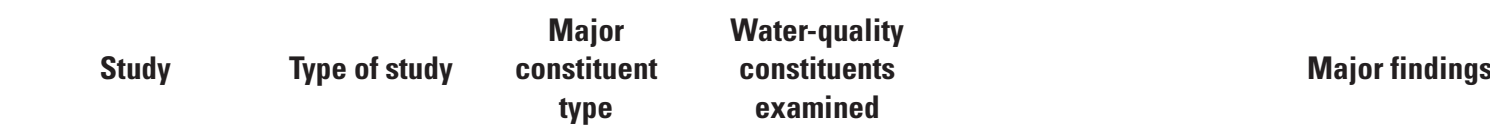

Yields of bedrock Water supply N/A None
wells in
Massachusetts.

Major bedrock type, topographic setting, and well construction all appeared to affect yields of wells. Highest yields were found in wells in valleys with thick overburden deposits, suggesting recharge from overburden is a source of water to bedrock wells. Bedrock included three major types: crystalline, carbonate, and noncarbonate sedimentary (typically low-grade metamorphosed sedimentary units). Crystalline rock primarily consisted of granite, gneiss, and schist.

\begin{tabular}{|c|c|c|c|c|}
\hline $\begin{array}{l}\text { Geologic framework } \\
\text { for ground-water } \\
\text { resources in } \\
\text { Central Vermont. }\end{array}$ & Water supply & N/A & None & $\begin{array}{l}\text { Analyzed relations between well yield and (1) lithologic and surficial units, } \\
\text { (2) proximity to topographic lineaments, (3) surficial material thickness and } \\
\text { permeability, (4) surface-water proximity, (5) major bedrock structures, } \\
\text { (6) slope and other topographic indices, and (7) drainage area. Found bedrock } \\
\text { type and topography related to well yield. Other factors were less important. }\end{array}$ \\
\hline $\begin{array}{l}\text { Fracture charac- } \\
\text { terization for } \\
\text { Nashoba Terrane, } \\
\text { Massachusetts. }\end{array}$ & Water supply & N/A & None & $\begin{array}{l}\text { Mapping of crystalline rock based on hydrostructural domain to quantify } \\
\text { hydraulic properties and generate regional conceptual models of flow. The } \\
\text { mapping of hydrostructural domains include rock type, number of distribu- } \\
\text { tion of fracture sets, type of fractures present or absent, degree of fracture } \\
\text { development, fracture spacing, and nature of fracture termination. Informa- } \\
\text { tion is compiled at the regional, quadrangle, and local well-field scales. }\end{array}$ \\
\hline
\end{tabular}

\begin{tabular}{|c|c|c|c|c|}
\hline $\begin{array}{l}\text { Factors related to } \\
\text { well yields in } \\
\text { New Hampshire. }\end{array}$ & Water supply & N/A & None & $\begin{array}{l}\text { Well depth, proximity to lineaments, plutons, slope of land, and some rock types } \\
\text { were found to correlate with well yields. Many of the intrusive rocks posi- } \\
\text { tively correlated with high well yield. Fine-grained metasediments negatively } \\
\text { correlated with well yield including phyllites, metapelite, and some schist. } \\
\text { Foliated plutons negatively correlated, whereas nonfoliated plutons positively } \\
\text { correlated with yield. }\end{array}$ \\
\hline
\end{tabular}

\begin{tabular}{|c|c|c|c|c|}
\hline $\begin{array}{l}\text { Water sources to } \\
\text { public supply } \\
\text { wells in fractured } \\
\text { bedrock. }\end{array}$ & Water supply & N/A & None & $\begin{array}{l}\text { Characteristics of ductile features (foliation and folds) were used to build } \\
\text { conceptual models of flow and input into numerical models. In areas where } \\
\text { foliation produces high-angle faults, leakage rates from overlying surficial } \\
\text { material is important in controlling sources of water to pumped wells. }\end{array}$ \\
\hline $\begin{array}{l}\text { Geochemical } \\
\text { comparison of } \\
\text { ground water in } \\
\text { the Northeast. }\end{array}$ & Water quality & $\begin{array}{l}\text { Natural } \\
\quad \text { contaminant }\end{array}$ & Major ions & $\begin{array}{l}\text { Calcite undersaturated with regard to crystalline rock ground water of the } \\
\text { New England area. Water chemistry suggests water reacting with feldspathic } \\
\text { minerals. }\end{array}$ \\
\hline $\begin{array}{l}\text { Water quality in } \\
\text { New Hampshire. }\end{array}$ & Water quality & $\begin{array}{l}\text { Natural } \\
\quad \text { contaminant }\end{array}$ & $\begin{array}{l}\mathrm{pH} \text {, hardness, } \\
\text { iron, manga- } \\
\text { nese, fluoride, } \\
\text { arsenic, radon. }\end{array}$ & $\begin{array}{l}\text { Bedrock water quality varied by lithochemical groupings. Bedrock units are } \\
\text { grouped by lithochemical characteristics based on mineralogic and chemical } \\
\text { properties that include reactivity of minerals to dissolution and presence of } \\
\text { carbonate and sulfide minerals. Radon potential was grouped separately on } \\
\text { the basis of lithology and mineralogy of uranium content, including two-mica } \\
\text { granite and pegmatites. }\end{array}$ \\
\hline
\end{tabular}

\begin{tabular}{|c|c|c|c|c|}
\hline $\begin{array}{l}\text { Water quality in } \\
\text { New England. }\end{array}$ & Water quality & $\begin{array}{l}\text { Natural } \\
\quad \text { contaminant }\end{array}$ & Arsenic & $\begin{array}{l}\text { Bedrock water quality positively correlated with bedrock whole-rock arsenic } \\
\text { concentrations. The distribution of bedrock geology features at the geologic- } \\
\text { province, lithology-group, and map-unit level closely correlate with areas of } \\
\text { elevated arsenic in ground water. }\end{array}$ \\
\hline
\end{tabular}

\begin{tabular}{ccc}
\hline $\begin{array}{c}\text { Water quality in } \\
\text { New England. }\end{array}$ & Water quality & $\begin{array}{c}\text { Natural } \\
\text { contaminant }\end{array}$
\end{tabular}

Bedrock water quality positively correlated with bedrock geology. Bedrock ground-water quality samples from wells located in rocks grouped under calcareous metasedimentary were found to contain the highest arsenic concentrations. 
compounds; mg/L, milligrams per liter]

\section{Factors assessed ( $\mathrm{X}$ = ASSESSED; $\mathrm{XX}=$ MEANS IMPORTANT EXPLANATORY VARIABLE)}

\begin{tabular}{|c|c|c|c|c|c|c|c|c|c|c|c|c|}
\hline $\begin{array}{c}\text { Structure } \\
\text { (R = Regional, } \\
\text { L = Local) }\end{array}$ & $\begin{array}{c}\text { Fracture } \\
\text { patterns } \\
\text { (R = Regional, } \\
\text { L = Local) }\end{array}$ & $\begin{array}{l}\text { Bed- } \\
\text { rock } \\
\text { type }\end{array}$ & $\begin{array}{c}\text { Geo- } \\
\text { chemical } \\
\text { con- } \\
\text { ditions }\end{array}$ & $\begin{array}{l}\text { Land } \\
\text { use }\end{array}$ & $\begin{array}{l}\text { Well } \\
\text { depth }\end{array}$ & $\begin{array}{l}\text { Well } \\
\text { diam- } \\
\text { eter }\end{array}$ & $\begin{array}{l}\text { Well } \\
\text { yield }\end{array}$ & $\begin{array}{l}\text { Topo- } \\
\text { graphic } \\
\text { setting }\end{array}$ & $\begin{array}{c}\text { Thick- } \\
\text { ness of } \\
\text { over- } \\
\text { burden }\end{array}$ & $\begin{array}{l}\text { Type of } \\
\text { over- } \\
\text { burden } \\
\text { material }\end{array}$ & $\begin{array}{l}\text { Year of } \\
\text { con- } \\
\text { struction }\end{array}$ & Author \\
\hline & & $\mathrm{X}$ & N/A & & $\mathrm{X}$ & $\mathrm{X}$ & $\mathrm{X}$ & $X X$ & $\mathrm{X}$ & & $\mathrm{X}$ & Hansen and Simcox (1994) \\
\hline
\end{tabular}

\begin{tabular}{llllllllllllll}
\hline X & X & XX & N/A & & X & X & X & X & X & $\begin{array}{c}\text { http://www.anr.state.vt.us/dec/ } \\
\text { geo/grndwaterWorc.htm }\end{array}$
\end{tabular}

\begin{tabular}{lllllllll}
\hline$X$ & $X$ & N/A & $X$ & $X$ & $\begin{array}{r}\text { X } \\
\text { http://water.usgs.gov/wri/02- } \\
\text { 03grants_new/prog-compl- } \\
\text { reports/2003MA19G.pdf }\end{array}$
\end{tabular}

\begin{tabular}{llllllllllllllll}
\hline $\mathrm{XX}$ & $\mathrm{XX}$ & $\mathrm{XX}$ & N/A & N/A & XX & N/A & XX & XX & X & & X & & Moore and others (2002a)
\end{tabular}

XX $\quad$ Rogers (1989)


Table 4. Summary of factors affecting regional water quality in crystalline rocks of the New England area.-Continued

[N/A, not applicable; mg/kg, milligrams per kilograms; As, arsenic; U, uranium; ppm, parts per million; MTBE, methyl tert-butyl ether; VOCs, volatile organic

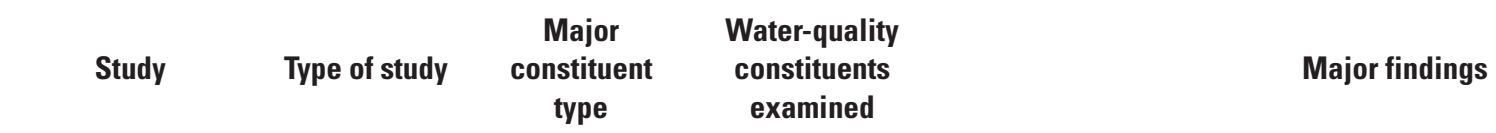

\begin{tabular}{|c|c|c|c|}
\hline $\begin{array}{l}\text { Geochemical } \\
\text { patterns of } \\
\text { arsenic enriched } \\
\text { ground water in } \\
\text { Northport, Maine. }\end{array}$ & Geochemistry & $\begin{array}{l}\text { Natural } \\
\quad \text { contaminant }\end{array}$ & Arsenic \\
\hline
\end{tabular}

Found that mineralogic differences in fractured rock is an important factor in high arsenic on the basis of the association of high silica and arsenic concentrations, which suggest dissolution of clays from granite intrusions. The adsorption and dissolution of arsenic from iron oxhydroxides, although a factor, is not a primary cause given the lack of a strong correlation with $\mathrm{pH}$. The bedrock water with the highest arsenic was surmised to be of intermediate evolution between a calcium-bicarbonate water type (modern recharge) and a sodium-bicarbonate (old) water type. Sodium-bicarbonate water type can be from silicate hydrolysis when longer residence time allows for the dissolution of sodium-feldspar or from exchange of calcium for sodium.

\begin{tabular}{llcc}
\hline $\begin{array}{l}\text { Mineralogy of } \\
\text { arsenic in } \\
\text { New Hampshire. }\end{array}$ & Geochemistry & $\begin{array}{c}\text { Natural } \\
\text { contaminant }\end{array}$ & Arsenic \\
& & \\
& & & \\
\hline $\begin{array}{l}\text { Hydrogeologic } \\
\text { controls on }\end{array}$ & Geochemistry & Natural & Radon, \\
radon-222 in & & contaminant & Uranium \\
fractured bedrock & & & \\
aquifer, Rhode & & & \\
Island. & & &
\end{tabular}

Pegmatite dike intruded into the Silurian lower Rangeley Formation, a metapelite, in central New Hampshire, found to contain high concentration $(59 \mathrm{mg} / \mathrm{kg}$ ) of As in the form of arsenopyrite and scorodite. The exposure to oxidizing conditions is believed to have initiated the dissolution of arsenopyrite into scorodite and release of As into ground water.

Although $\mathrm{U}$ content of one granite and two gneiss rocks were not that different (ranging from 1.9 to $4.1 \mathrm{ppm}$ ), large differences occurred in ground-water samples for radon that suggest emination differences in the rock. Fluoride and alkalinity were found to be markers of suggesting increased weathering of fracture faces that facilitated the release of $U$ and production of radon-222. Zones of elevated bedrock $U$ may be associated with shear zones and formation of mylonites. Shear zones create foliation and preferential concentration of $\mathrm{U}$.

\begin{tabular}{ccc}
\hline $\begin{array}{l}\text { Water quality in } \\
\text { New England. }\end{array}$ & Water quality & $\begin{array}{r}\text { Anthropogenic } \\
\text { contaminant }\end{array}$
\end{tabular}

An analysis of MTBE concentrations in ground water from crystalline rock of southeastern New Hampshire showed that land use and population density were important factors to detection of MTBE. Well yield was inversely related to MTBE concentrations, whereas low-yield wells showed higher MTBE concentrations. Bedrock type did not correlate with MTBE, indicating no significant relation between well yield and bedrock type for this area.

\begin{tabular}{|c|c|c|c|c|}
\hline $\begin{array}{l}\text { National occurrence } \\
\text { of VOCs. }\end{array}$ & Water quality & $\begin{array}{r}\text { Anthropogenic } \\
\text { contaminant }\end{array}$ & VOCs & $\begin{array}{l}\text { Crystalline rock aquifers from the New England area showed a high frequency } \\
\text { of VOC detection compared to other principal aquifers throughout the } \\
\text { U.S. Factors such as source, transport, and geochemical conditions (oxygen } \\
\text { levels in aquifer) affected occurrence. }\end{array}$ \\
\hline $\begin{array}{l}\text { Water quality in } \\
\text { New England } \\
\text { Coastal Basins. }\end{array}$ & Water quality & $\begin{array}{r}\text { Anthropogenic } \\
\text { contaminant }\end{array}$ & $\begin{array}{l}\text { VOCs, } \\
\text { pesticides, } \\
\text { nitrates }\end{array}$ & $\begin{array}{l}\text { One detection of VOC contaminant occurred in } 30 \text { percent of } 58 \text { domestic } \\
\text { bedrock wells. The most common contaminants were MTBE, chloroform, } \\
\text { 1,1,1-trichloroethane, TAME (tert-amyl-methyl ether), and PCE (tetrachlo- } \\
\text { roethylene). Pesticides were detected in only } 10 \text { percent of } 56 \text { wells. Nitrate } \\
\text { concentration was low in domestic bedrock wells-less than } 0.05 \mathrm{mg} / \mathrm{L} \text { in } \\
\text { nearly } 60 \text { percent of } 58 \text { domestic bedrock wells. }\end{array}$ \\
\hline $\begin{array}{l}\text { Road salt in } \\
\text { bedrock wells } \\
\text { in Maine. }\end{array}$ & Water quality & $\begin{array}{r}\text { Anthropogenic } \\
\text { contaminant }\end{array}$ & Road salt & $\begin{array}{l}\text { Negative correlations between low water levels and high chloride concentrations } \\
\text { in bedrock wells in Maine suggest chloride sequestering (accumulation of } \\
\text { chloride in dead-end fractures or fractures that contribute flow during low- } \\
\text { flow periods). }\end{array}$ \\
\hline $\begin{array}{l}\text { Geochemical condi- } \\
\text { tions around } \\
\text { Augusta, Maine. }\end{array}$ & Water quality & $\begin{array}{r}\text { Anthropogenic } \\
\text { contaminant }\end{array}$ & Nitrate & $\begin{array}{l}\text { Collection of geochemical data showed that, although several trace elements } \\
\text { were at high concentrations, including arsenic, concentrations of nitrate from } \\
600 \text { wells generally were low, about } 1.1 \mathrm{mg} / \mathrm{L} \text {. }\end{array}$ \\
\hline
\end{tabular}


compounds; mg/L, milligrams per liter]

\section{Factors assessed ( $\mathrm{X}$ = ASSESSED; $\mathrm{XX}=$ MEANS IMPORTANT EXPLANATORY VARIABLE)}

\begin{tabular}{|c|c|c|c|c|c|c|c|c|c|c|c|c|}
\hline $\begin{array}{c}\text { Structure } \\
\text { (R = Regional, } \\
\text { L = Local) }\end{array}$ & $\begin{array}{c}\text { Fracture } \\
\text { patterns } \\
\text { (R = Regional, } \\
\text { L = Local) }\end{array}$ & $\begin{array}{l}\text { Bed- } \\
\text { rock } \\
\text { type }\end{array}$ & $\begin{array}{c}\text { Geo- } \\
\text { chemical } \\
\text { con- } \\
\text { ditions }\end{array}$ & $\begin{array}{c}\text { Land } \\
\text { use }\end{array}$ & $\begin{array}{l}\text { Well } \\
\text { depth }\end{array}$ & $\begin{array}{l}\text { Well } \\
\text { diam- } \\
\text { eter }\end{array}$ & $\begin{array}{l}\text { Well } \\
\text { yield }\end{array}$ & $\begin{array}{l}\text { Topo- } \\
\text { graphic } \\
\text { setting }\end{array}$ & $\begin{array}{c}\text { Thick- } \\
\text { ness of } \\
\text { over- } \\
\text { burden }\end{array}$ & $\begin{array}{c}\text { Type of } \\
\text { over- } \\
\text { burden } \\
\text { material }\end{array}$ & $\begin{array}{c}\text { Year of } \\
\text { con- } \\
\text { struction }\end{array}$ & Author \\
\hline & & $\mathrm{XX}$ & $\mathrm{XX}$ & $\mathrm{X}$ & & & & $\mathrm{X}$ & & & & Lipert and others (2006) \\
\hline
\end{tabular}

\begin{tabular}{llllllllllllllll}
\hline XX & X & XX & X & X & X & X & & X & & Veeger and Ruderman (1998)
\end{tabular}

\begin{tabular}{lllll}
\hline $\mathrm{X}$ & $\mathrm{XX}$ & $\mathrm{XX}$ & $\mathrm{XX}$
\end{tabular}

$\mathrm{XX} \quad \mathrm{XX} \quad \mathrm{X}$


Appendix 1. Summary of regional ground-water-quality issues in ground water of the New England area, by state, as reported by state

[VOCs, volatile organic compounds; MCLs, Maximum Contaminant Levels, U.S. Environmental Protection Agency standards unless otherwise specified; Protection Agency Health Advisory Level; Sb, antimony; As, arsenic; Cd, cadmium; Pb, lead; Mn, manganese; Fe, iron; Be, beryllium; MTBE, methyl tert-butyl ether;

\begin{tabular}{|c|c|c|c|c|c|}
\hline \multirow{3}{*}{ State } & \multirow{3}{*}{ Type of study } & \multirow{3}{*}{ Major findings } & \multicolumn{3}{|c|}{ Water-quality issues } \\
\hline & & & \multicolumn{3}{|c|}{ Anthropogenic } \\
\hline & & & VOCs & Nutrients & Bacteria \\
\hline Vermont & $\begin{array}{l}\text { Regional water quality monitor- } \\
\text { ing of public community and } \\
\text { non-transient systems. Not } \\
\text { differentiated with regard to } \\
\text { rock type. Second study on } \\
\text { agricultural activities includes } \\
1,294 \text { monitoring wells; also } \\
\text { not differentiated by rock type. } \\
\text { Limited data from private wells } \\
\text { (80 percent set in bedrock). }\end{array}$ & $\begin{array}{l}\text { Bacteria problems were reported } \\
\text { for many public supply wells } \\
\text { in state. }\end{array}$ & $\begin{array}{l}\text { Twenty-eight public } \\
\text { systems out of } \\
\text { unknown number had } \\
\text { VOCs above MCLs } \\
\text { of } 5 \mu \mathrm{g} / \mathrm{L} \text {. }\end{array}$ & $\begin{array}{l}\text { Nine public systems out of } \\
\text { an unknown number had } \\
\text { nitrate concentrations } \\
\text { above } 5 \mu \mathrm{g} / \mathrm{L}(10 \mu \mathrm{g} / \mathrm{L} \\
\text { is MCL). Seventy-eight } \\
\text { (6 percent) agricultural } \\
\text { wells exceed of the MCL } \\
(10 \mathrm{mg} / \mathrm{L}) \text { for nitrate. }\end{array}$ & $\begin{array}{l}\text { One hundred thirteen } \\
\text { public systems out } \\
\text { of unknown num- } \\
\text { ber tested positive } \\
\text { for bacteria } \\
\text { contamination. }\end{array}$ \\
\hline New York & $\begin{array}{l}\text { Regional water-quality monitoring } \\
\text { of public community and non- } \\
\text { transient systems. }\end{array}$ & $\begin{array}{l}\text { None reported for crystalline rock } \\
\text { for large systems (more than } \\
100,000 \text { served). }\end{array}$ & & & \\
\hline Massachusetts & $\begin{array}{l}\text { Regional water-quality monitoring } \\
\text { of public community and non- } \\
\text { transient systems. Not differenti- } \\
\text { ated with regard to rock type. }\end{array}$ & $\begin{array}{l}\text { Sixty-nine percent of regional } \\
\text { water quality supplies rely on } \\
\text { ground water. Major problem } \\
\text { was coliform bacteria. No } \\
\text { other detailed information } \\
\text { provided. }\end{array}$ & Not reported. & Not reported. & Not reported. \\
\hline Rhode Island & $\begin{array}{l}\text { Regional water-quality monitoring } \\
\text { of public community and non- } \\
\text { transient systems. Not differenti- } \\
\text { ated with regard to rock type. }\end{array}$ & $\begin{array}{l}\text { Bacteria from septic systems } \\
\text { identified as a problem. }\end{array}$ & $\begin{array}{l}\text { MTBE and solvent } \\
\text { organics detected the } \\
\text { most. }\end{array}$ & $\begin{array}{l}\text { Median concentration of } \\
\text { nitrate was } 2 \mathrm{mg} / \mathrm{L} \text { out } \\
\text { of unknown number of } \\
\text { samples. }\end{array}$ & Common problem. \\
\hline $\begin{array}{l}\text { New } \\
\text { Hampshire }\end{array}$ & $\begin{array}{l}\text { Ground water from private wells. } \\
\text { Not differentiated with regard } \\
\text { to rock type but generally set in } \\
\text { crystalline rock aquifers. }\end{array}$ & $\begin{array}{l}\text { Bedrock well-water quality is } \\
\text { sometimes affected by natu- } \\
\text { rally occurring contaminants } \\
\text { including fluoride, arsenic, } \\
\text { mineral radioactivity, and } \\
\text { radon gas. }\end{array}$ & $\begin{array}{l}\text { Nineteen of } 65 \text { wells } \\
\text { had levels exceeding } \\
\text { MCLs of } 5 \mu \mathrm{g} / \mathrm{L} \text {. }\end{array}$ & $\begin{array}{l}\text { Seventeen of } 1999 \text { wells } \\
\text { had levels above MCL. }\end{array}$ & Not reported. \\
\hline Maine & $\begin{array}{l}\text { Ambient ground-water-quality } \\
\text { monitoring-well data. Generally } \\
\text { differentiated by rock type. }\end{array}$ & $\begin{array}{l}\text { No detections above MCL of } \\
5 \mu \mathrm{g} / \mathrm{L} \text { for VOCs were mea- } \\
\text { sured out of } 1,196 \text { public water } \\
\text { supply wells sampled in crys- } \\
\text { talline rock. Nitrate concentra- } \\
\text { tions were below MCL of } \\
10 \mu \mathrm{g} / \mathrm{L} \text {. Chloride concentra- } \\
\text { tions high in many wells. }\end{array}$ & Below MCLs. & $\begin{array}{l}\text { Generally below MCL of } \\
10 \mu \mathrm{g} / \mathrm{L} \text { for nitrate. }\end{array}$ & $\begin{array}{l}\text { Fourteen percent } \\
\text { of wells tested } \\
\text { positive for total } \\
\text { coliform or } \\
\text { E. coli. }\end{array}$ \\
\hline New Jersey & $\begin{array}{l}\text { Ambient ground-water-quality } \\
\text { monitoring-well data (150 total } \\
\text { wells). Not differentiated by } \\
\text { rock type but region—northern } \\
\text { and southern New Jersey—and } \\
\text { by land use-agricultural, urban, } \\
\text { and undeveloped. }\end{array}$ & $\begin{array}{l}\text { In northern New Jersey, } \mathrm{Sb}, \mathrm{As} \text {, } \\
\mathrm{Cd}, \mathrm{Pb} \text {, and } \mathrm{Mn} \text {, appear to be } \\
\text { mostly natural in origin. Fe and } \\
\text { Be have an urban association. }\end{array}$ & $\begin{array}{l}\text { Thirty-eight out of } 148 \\
\text { network wells had } \\
\text { detectable concentra- } \\
\text { tions of MTBE. }\end{array}$ & $\begin{array}{l}\text { Generally concentrations } \\
\text { are low, below MCLs. }\end{array}$ & Not reported. \\
\hline Connecticut & $\begin{array}{l}\text { Reports from } 600 \text { non-community } \\
\text { ground-water systems. Not } \\
\text { differentiated by rock type. }\end{array}$ & $\begin{array}{l}\text { MTBE, heating oils, and VOCs } \\
\text { most common contaminants. }\end{array}$ & $\begin{array}{l}\text { MTBE, heating oils, and } \\
\text { VOCs most common } \\
\text { contaminants. }\end{array}$ & $\begin{array}{l}\text { Unknown number of viola- } \\
\text { tions exceeded for nitrate } \\
\text { MCL. }\end{array}$ & $\begin{array}{l}\text { One hundred eighty } \\
\text { six systems out of } \\
600 \text { tested posi- } \\
\text { tive for bacteria } \\
\text { contamination. }\end{array}$ \\
\hline
\end{tabular}

References:

Connecticut Department of Environmental Protection, 2006, 2006 Integrated Water Quality Report to Congress, prepared pursuant to Federal Clean Water Act, Sections 305(b)

New Hampshire Department of Environmental Services, 2000, State of New Hampshire, 2000, Section 305(b), Water Quality Report: Concord, N.H.

New Hampshire Department of Environmental Services, 2006, State of New Hampshire, 2000, Section 305(b), Water Quality Report: Concord, N.H.

Vermont Department of Environmental Conservation, 2004, State of Vermont, 2004, Water Quality Assessment Report (305(b) report): Vermont Department of Environmental 
environmental agencies.

$\mu \mathrm{g} / \mathrm{L}$, micrograms per liter; mg/L, milligrams per liter; N/A, not applicable; $\mathrm{pCi} / \mathrm{L}$, picocuries per liter; ppb, parts per billion; EPA HAL, U.S. Environmental

TDS, total dissolved solids; E. coli, Escherichia coli]

Water-quality issues

\begin{tabular}{|c|c|c|c|c|c|c|}
\hline \multicolumn{4}{|c|}{ Anthropogenic } & \multicolumn{3}{|c|}{ Natural } \\
\hline Pesticides & $\begin{array}{l}\text { Emerging } \\
\text { contami- } \\
\text { nants }\end{array}$ & Road salt & $\begin{array}{l}\text { Salt-water } \\
\text { intrusion }\end{array}$ & Metals & Radionuclides & Other source of information \\
\hline $\begin{array}{l}\text { One well out of } 1,294 \\
\text { agricultural wells } \\
\text { tested above MCL } \\
\text { for herbicides. }\end{array}$ & N/A & Not reported. & N/A & $\begin{array}{l}\text { Five public } \\
\text { systems } \\
\text { above MCL } \\
(10 \mu \mathrm{g} / \mathrm{L}) \text { for } \\
\text { arsenic. }\end{array}$ & $\begin{array}{l}\text { Nine public systems with } \\
\text { gross alpha above } \\
10 \mathrm{pCi} / \mathrm{L}(15 \mathrm{pCi} / \mathrm{L} \text { is } \\
\text { the } \mathrm{MCL})\end{array}$ & $\begin{array}{l}\text { Vermont Department of } \\
\text { Environmental Conserva- } \\
\text { tion (2004) }\end{array}$ \\
\hline
\end{tabular}

N/A N/A

\begin{tabular}{lllll}
\hline Not reported. N/A & Not reported. & Not reported. & None reported. & None reported. \\
& & & 305b/2000report/chp6.pdf
\end{tabular}

\begin{tabular}{|c|c|c|c|c|c|c|}
\hline $\begin{array}{l}\text { Not typically detected } \\
\text { in samples. }\end{array}$ & N/A & $\begin{array}{l}\text { An unknown number of } \\
\text { municipal wells reported } \\
\text { to have sodium concentra- } \\
\text { tions exceeding } 20 \mathrm{mg} / \mathrm{L} \text {. }\end{array}$ & Not reported. & None reported. & $\begin{array}{l}\text { Out of } 101 \text { samples in } \\
\text { Pawcatuck River Basin, } \\
\text { only two samples had } \\
\text { radon concentrations } \\
\text { below } 500 \mathrm{pCi} / \mathrm{L} \text {. }\end{array}$ & $\begin{array}{l}\text { http://www.dem.ri.gov/ } \\
\text { pubs/305b/four.pdf }\end{array}$ \\
\hline Not reported. & N/A & $\begin{array}{l}\text { Sodium contamination is of } \\
\text { concern from road salting. }\end{array}$ & Not reported. & None reported. & None reported. & $\begin{array}{l}\text { New Hampshire Department } \\
\text { of Environmental Science } \\
(2000,2006)\end{array}$ \\
\hline
\end{tabular}

\begin{tabular}{|c|c|c|c|c|c|c|}
\hline $\begin{array}{l}\text { Median concentrations } \\
\text { of hexazinone, a } \\
\text { pesticide, in } 49 \text { wells } \\
\text { tested in Maine, was } \\
0.43 \text { ppb. The EPA } \\
\text { HAL is } 400 \text { ppb. }\end{array}$ & N/A & $\begin{array}{l}\text { One hundred fifty drinking- } \\
\text { water wells with chloride } \\
\text { concentrations exceeding } \\
250 \mathrm{mg} / \mathrm{L} \text { (State secondary } \\
\text { drinking water level). }\end{array}$ & $\begin{array}{l}\text { Common on } \\
\text { coastal } \\
\text { peninsulas } \\
\text { and offshore } \\
\text { islands of } \\
\text { Maine. }\end{array}$ & None reported. & None reported. & $\begin{array}{l}\text { http://www.maine.gov/dep/ } \\
\text { blwqdocmonitoring/305b/ } \\
\text { 2006/2006_Draft_305b _ } \\
\text { Report_Section3.pdf }\end{array}$ \\
\hline
\end{tabular}

\begin{tabular}{|c|c|c|c|c|c|c|}
\hline $\begin{array}{l}\text { Concentrations low } \\
\text { in all land use } \\
\text { categories. }\end{array}$ & N/A & $\begin{array}{l}\text { Higher TDS reported for } \\
\text { wells in urban }(550 \mathrm{mg} / \mathrm{L} \\
\text { median value) and agri- } \\
\text { cultural areas ( } 269 \mathrm{mg} / \mathrm{L} \\
\text { median value). }\end{array}$ & N/A & $\begin{array}{l}\text { See major find- } \\
\text { ings. }\end{array}$ & $\begin{array}{l}\text { Concentrations of } \\
\text { radium-224 have been } \\
\text { shown to be affected } \\
\text { by land use and that } \\
\text { agricultural and lawn- } \\
\text { chemical products can } \\
\text { compete with naturally } \\
\text { occurring radium and } \\
\text { mobilize radium. }\end{array}$ & $\begin{array}{l}\text { http://www.state.nj.us/ } \\
\text { dep/wms/bwqsa/ } \\
\text { docs/2006AppendixI } \\
\text { AmbientGWQMN.pdf }\end{array}$ \\
\hline Not reported. & Not reported. & Not reported. & Not reported. & None reported. & $\begin{array}{l}\text { Unknown number of } \\
\text { violations exceeded for } \\
\text { radionuclide MCLs. }\end{array}$ & $\begin{array}{l}\text { Connecticut Department of } \\
\text { Environmental Protection } \\
(2006)\end{array}$ \\
\hline
\end{tabular}

and 303(d): State of Connecticut Department of Environmental Protection Bureau of Waste Management, Hartford, Conn.

Conservation: Waterbury, Vt. 